\title{
Psikoterapi Araştırmalarında Konuşma Çözümlemesi: Yöntemsel Bir Gözden Geçirme
}

\section{Conversation Analysis in Psychotherapy Research: A Methodological Review}

\author{
İlknur Dilekler ${ }^{1}$ (1)
}

'Dr. Öğr. Üyesi, TOBB Ekonomi ve Teknoloji Üniversitesi, Fen Edebiyat Fakültesi, Psikoloji Bölümü, Ankara, Türkiye

ORCID: I.D. 0000-0002-9231-8141

Sorumlu yazar/Corresponding author: İlknur Dilekler,

TOBB Ekonomi ve Teknoloji Üniversitesi, Fen Edebiyat Fakültesi, Psikoloji Bölümü, Söğütözü caddesi, No. 43, 06560, Söğütözü, Ankara, Türkiye

E-posta/E-mail: idilekler@etu.edu.tr

Başvuru/Submitted: 25.10 .2019

Kabul/Accepted: 25.06 .2020

Online Yayın/Published Online: 25.02.2021

Citation/Atıf: Dilekler, İ. (2021). Psikoterapi araştırmalarında konuşma çözümlemesi:

Yöntemsel bir gözden geçirme. Psikoloji Çalıșmaları - Studies in Psychology, 41(1): $1-34$

https://doi.org/10.26650/SP2019-0081
ÖZ

Konuşma çözümlemesi sosyal bilimler içinde gelişme göstermiş, temel olarak doğal konuşmaları inceleyen ve konuşmacıların etkileşimlerine dair belirli özellikleri açığa çıkaran bir nitel araştırma yöntemidir. Psikoterapi araştırmaları nicel ve nitel pek çok farklı araştırma yöntemini kullanarak psikoterapi süreci ve etkililiğini belirleyen özellikleri anlamayı hedeflemiş̧ir. Psikoterapide uzmanlar ve danışanlar arasındaki etkileşime dair öğeler bu özelliklerden biri olarak görülmüş ve konuşma çözümlemesi de psikoterapi araştırmalarında kullanılan yöntemlerden biri haline gelmiştir. Ülkemizde konuşma çözümlemesi sosyoloji, eğitim bilimleri ve psikolojinin çeşitli alt alanlarında bir araştırma yöntemi olarak daha bilinir olmakla birlikte psikoterapi araştırmaları özelinde konuşma çözümlemesinin ne tür sorulara cevap verebileceği ile ilgili Türkçe kaynak eksikliği bulunmaktadır. Bu nedenle bu yazı konuşma çözümlemesinin psikoterapi araştırmalarında nasıl kullanıldığı ile ilgili temel kuramsal ve yöntemsel konuları ve alan yazındaki çalışmaları gözden geçirmeyi amaçlamaktadır. Konuşma çözümlemesini kullanarak psikoterapi etkileşimlerini inceleyen çalışmalar yorumsamacı psikoterapi araştırmaları geleneği içinde değerlendirilmektedir. Konuşma çözümlemesi temel varsayımları ve kendine özgü analiz yöntemleri ile terapist ve danışanların psikoterapi sürecini ortak bir şekilde nasıl inşa ettikleri ve süreçteki değişimlerin hangi konuşma araçları yoluyla hayata geçirildiğine dair çıkarımlar yapmaya imkan vermektedir. Psikoterapi araştırmaları alan yazınında konuşma çözümlemesi kullanılarak yapılan çalışmalar pek çok sorunun cevabını aramaktadır. Şimdiye kadar yapılan araştırmaların terapötik müdahaleler, terapi ilişkisine dair öğeler ve psikoterapinin etkilerini anlamak gibi üç temel çalışma alanı etrafında şekillendiği söylenebilir. Bu yazıda da alan yazındaki bulguların özetlenmesiyle çalışmaların psikoterapi pratiğine dair çıkarımlarına yer verilmekte ve son dönemde ön plana çıkan araştırma eğilimlerinden söz edilmektedir. Aynı zamanda Türkçe bir psikoterapi kesitinin örnek analizine de yer verilmektedir. Son olarak, psikoterapide konuşma analizinin, bireysel ve kültürel olarak uyarlanmış psikoterapi uygulamalarına kayda değer katkıları olduğu sonucuna varılmıştır. Psikoterapide sonuç araştırmaları ve karma yöntemli araştırma tasarımlarının da gelecekte öne çıkacağı düşünülmektedir.

Anahtar Kelimeler: Konuşma çözümlemesi, psikoterapi, psikoterapi araştırması, araştırma metodu, nitel araştırma, sosyal etkileşim 


\section{ABSTRACT}

Conversation analysis is a qualitative research method developed in social sciences that inspects naturally occurring conversations and reveals the particular characteristics of conversationalists' interactions. Psychotherapy research aims to understand the features that determine the psychotherapy process and its effectiveness by using many different qualitative and quantitative research methods. The characteristics of interactions between psychotherapists and clients in psychotherapy are one of these features, and conversation analysis has become one of the methods used in psychotherapy research. Although conversation analysis in Turkey is better known as a research method in sociology, educational sciences, and various subfields of psychology, there is a lack of Turkish resources on the kind of questions conversation analysis can answer in psychotherapy research. Hence, the current article provides theoretical and methodological information about how conversation analysis is utilized in psychotherapy research and reviews the literature. Studies examining psychotherapy interactions using this method belong to the psychotherapy research tradition based on hermeneutics. Conversation analysis makes inferences about how therapists and clients jointly construct the psychotherapy process and how changes take place using its unique assumptions and analysis methods. In the psychotherapy research literature, conversation analysis studies have sought answers to many questions. The research hitherto has evolved around three main areas of study: therapeutic interventions, elements of the therapeutic relationship, and the effects of psychotherapy. In this paper, the literature findings are summarized and the implications of these studies for the practice of psychotherapy and recent research trends are touched upon. Furthermore, the analysis of a Turkish psychotherapy extract is illustrated. Finally, the article concludes that conversation analysis in psychotherapy makes noteworthy contributions to individually and culturally tailored psychotherapy practice. Research on psychotherapy outcomes and mixed-method designs are expected to become prominent in the future.

Keywords: Conversation analysis, psychotherapy, psychotherapy research, research methodology, qualitative research, social interaction

\section{EXTENDED ABSTRACT}

Psychotherapy research has grown since the beginning of the 20th century with expanding questions related to the process and outcomes of psychotherapy (Rieken \& Gelo, 2015). There are two main research traditions within psychotherapy research literature: positivist and hermeneutic approaches (Braakmann, 2015). Within the hermeneutic approach, methods that aim to reveal the subjective and qualitative facets of psychotherapy practice are utilized. Conversation analysis (CA) is one of the qualitative methods used in psychotherapy research, but there is scarce information about the specific questions that can be answered and the main assumptions of this methodology in Turkish. Hence, this paper intends to raise theoretical and methodological issues about CA as it is utilized in psychotherapy research.

CA was first used in the analysis of suicide help-line conversations by Sacks, Schegloff, and Jefferson (1974). Since then, it has evolved to aid understanding of the micro characteristics of daily and institutional conversations in their natural context (Hutchby \& Wooffitt, 2008; Ten Have, 2007). Researchers using CA assume that human interaction is an action-oriented conversation that is designed in an orderly way and that there are asymmetries of power or social status between conversationalists. By considering the 
specific characteristics of interaction, it is possible to reveal how these assumptions operate in the conversation (Rapley, 2012). These characteristics include turn-taking organization, sequence organization, repair organization, organization of turn-design, lexical choice, and epistemological and other forms of asymmetry (Heritage, 1998).

The first CA of psychotherapy was Davis's (1986) study on problem reformulation. Perakyla, Antaki, Vehvilainen, \& Leudar (2008) point out that the development of CA studies in psychotherapy has taken place with intersections of various subject and research objectives. Nevertheless, therapeutic interventions, elements of the therapy relationship, and the effects of psychotherapy categorize these study frameworks in the most general terms.

Research on therapeutic interventions examines the specific tasks of psychotherapy. Formulations (Weiste \& Perakyla, 2013), interpretations (Vehvilainen, 2008), and questions (MacMartin, 2008) were the interventions most focused on in the very first CA studies. Research in this field not only helped to understand specific interventions but also identified distinctions between different therapeutic tasks. For instance, Bercelli, Rossano, and Viaro (2008) compared interpretations with formulations and concluded that therapists use formulations to emphasize the client's point of view and interpretations to represent their own.

Therapy relationship research has two focal elements related to the therapeutic alliance and relational dynamics of the psychotherapy interaction. As an element of the therapeutic alliance, investigations of conversations held by therapists and clients have examined affiliation, agreement, empathy or break of collaboration, and resistance patterns (e.g., Cardoso, Pinto, \& Ribeiro, 2019; Madill, Widdicombe, \& Barkham, 2001; Muntigl \& Horvart, 2014). Taking a break in collaboration as an example, studies show that silence (Cardoso et al., 2019), topic change (Madill et al., 2001), and answers like "I don't know" (Antaki, 2008; Hutchby, 2005) were the most encountered conversational strategies used by clients. The second research trend on the therapy relationship has implications for the specific characteristics of the psychotherapy relationship. Buchholtz, Spiekermann, and Kachele (2015), Sutherland and Strong (2011), and Dilekler (2018) are examples of researchers in this field who tried to discover the relational roles enacting the patterns such as the one who knows the other's mind role, sadistic or masochistic tendencies, and conflicts.

There have been remarkable studies of the effects of psychotherapy, including investigating interactive tools of therapeutic change with various client groups (e.g., Arminen, 2004) and psychotherapy approaches (e.g., Kondratyuk \& Perakyla, 2011). 
Understanding how changes occur in therapeutic conversations is another focus of CA studies, and as Perakyla and his colleagues (2008) suggested, implies the feasibility of CA for process-outcome studies in the near future.

\section{Discussion}

In summary, CA research in psychotherapy began by examining certain interventions, especially conceptualizations, continued by inquiring into issues like the therapeutic relationship and outcome research, which has come to the forefront recently. Studies have become increasingly powerful in their understanding of the issues related to the practice of psychotherapy. The fact that CA observes the psychotherapy interaction directly results not only in an accurate representation of the intersubjectivity of psychotherapy but also helps researchers base their elaborations on data that is accessible to all readers. CA's focus on asymmetries between conversationalists also equips researchers to dig into social and cultural matters. The implications for the individually tailored practice of psychotherapy are immense. It is expected that studies will be designed to address macro-dynamics and psychotherapy outcomes in the future. Mixed-method studies are also anticipated. CA studies in psychotherapy research are in their initial stages in Turkey. However, with the development of these studies, it will be possible to increase Turkish contributions to the practice of psychotherapy in general and to broaden knowledge of cultural-specific issues at a national level. 
Psikoterapi araştırması denilince en genel tanımıyla psikoterapiyi inceleme ve psikoterapi çalışmasında ne olup bittiğini anlamaya yönelik bir çabadan söz edilmektedir. $\mathrm{Bu}$ ilk ve en genel tanımlamayı, diğer tüm bilme çabalarında olduğu gibi, pek çok soru takip etmektedir. Bu sorulardan birkaçı "Psikoterapide ne anlaşılmaya çalışılmaktadır?", “Kim ya da kimler anlaşılmaya çalışılmaktadır?” ya da "Bu anlayış ne şekilde ve hangi araçlarla yapılabilir?” şeklinde sıralanabilir. Psikoterapiye dair sorular ele alınırken bu sorulara da nasıl cevaplar verildiği ya da hangi varsayımlarla hareket edildiği hususunda çeşitli ontolojik ve epistemolojik duruşlar ile uygulama açısından farklı yöntemsel yaklaşımlar bulunmaktadır (Rieken ve Gelo, 2015). Bu noktada, aynı zamanda psikoterapinin ne olduğu, neyi amaçladığ 1 , neleri dışarıda bıraktığı gibi konularla ilgili kuramsal yaklaşımların psikoterapi araştırmalarının çerçevesini oluşturmadaki rolü göz ardı edilmemelidir (Emanuela ve Carmela, 2013). Örneğin, kuramsal olarak davranış değişimini merkezine alan bir yaklaşım içinde psikoterapinin etkin olup olmadığının belirlenmesinde davranışlara dair çıktılar ele alınırken, bireyin kendisiyle ve diğerleriyle ilişki kurma örüntülerine dair içgörü edinmesine odaklı bir psikoterapi anlayışı temelinde yapılacak bir araştırma bu alandaki kazanımları değerlendirmeyi uygun bulabilir.

Konuşma çözümlemesi (KÇ) psikoterapi araştırmaları içinde kullanılan ve kendi epistemolojik bakış açısından psikoterapiyi ilgilendiren belli konularla ilgili soruları cevaplamaya yardımcı olan bir yöntemdir (Perakyla, 2013). Türkiye'de, sosyal bilimlerin genelinde daha fazla bilinmekle beraber, psikoterapi araştırmaları özelinde KÇ'nin ne gibi soruları cevapladığı, bunu yaparken nasıl yollar izlediği ve psikoterapi etkileşimlerini nasıl bir çerçevede ele aldığı ile ilgili kaynak ve derleme çalışmalarının eksikliği göze çarpmaktadır. Bu anlamdaki kuramsal ve yöntemsel konulara değinmeyi, alan yazındaki çalışmaların örneklerini sunmayı amaçlayan bu derleme, KÇ’ye dayalı çalışmaların psikoterapi araştırmaları içinde nasıl bir yerde durduğunu kavrayabilme imkanı sunacaktır. Bu amaçla önce hem psikoterapinin ve psikoterapi araştırmalarının hem de KÇ’nin tarihsel ve yöntemsel yolculuğuna k1saca değinilecektir.

\section{Psikoterapi Araştırmaları}

Psikoterapi araştırmalarının gelişimi psikoterapinin tarih boyunca nasıl bir gelişim, değişim ve çeşitlenme gösterdiğiyle yakından ilişkili olmuştur. Shean (2013) psikoterapi araştırmalarındaki yöntemsel tartışmaların odağına bir yanda doğa bilimi perspektifini diğer yanda anlam-temelli yaklaşımları koymuştur. Benzer şekilde, Braakmann (2015) psikoterapi araştırmalarını iki temel gelenekte ve ana hatlarıyla dört kronolojik 
dönemde gruplandırır. İki geleneğin, diğer bir deyişle araştırmaların psikoterapiyle ilgili bilgiye nasıl ulaşabileceğine dair yanıtın ilki mantıksal çıkarım, deneysellik ve çoğunlukla niceliksel veriye dayalı ölçülebilirlik çerçevesinde pozitivist çalışmalardır. İkincisi ise yapısal ve görüngübilimsel (fenomenolojik) nitelikleri anlamaya odaklı yorumsamac1 (hermeneutic) çalışmalardır.

Braakmann (2015) psikoterapi kavramının 1700'lü yıllara dayandığını hatırlatsa da araştırmaların doğumu olarak 1900'lü yılların başını işaret edip, bu dönemde özel uygulamalar ve vaka çalışmalarının baskın rolünden bahsetmektedir. Perakyla, Antaki, Vehvilainen ve Leudar (2008) ile Kuş (2007), Breuer ve Freud'un (1957) histeri çalışmaları gibi vaka raporlarının anlam temelli ve nitel psikoterapi çalışmalarının öncü örnekleri olduğu fikrini desteklemektedirler. Nicel verilere dayalı araştırmaların ilki olarak ise Neustatter'ın (1935) Lancet'te yayımlanan, elli farklı vakanın psikoterapi sürecini değerlendirdiği araştırması gösterilmektedir. Bu çalışmadan yalnızca bir yıl sonra ise tüm psikoterapi yönelimlerinin hangi kuramsal yaklaşıma dayalı olduğu fark etmeksizin etkili olduğu öne sürülmüştür (Rozenzweig, 1936). Ancak oldukça ses getiren bu bulgu, Eysenck (1952) tarafından psikoterapinin rastlantısal bir iyileşmenin ötesinde fayda göstermediği iddiası ile eleştirilmiştir. Bu eleştiriler Carl Rogers ve ekibinin ilk kez sistemli şekilde psikoterapi kayıtlarını incelemesi ile sonuçlanmış ve sonraki dönemler için de önemli olacak temel araştırma sorularının filizlenmesini sağlamıştır (Elliott ve Farber, 2010). Bunlardan ilki psikoterapinin işe yarayıp yaramadığ 1 (sonuç), diğeri psikoterapi sürecinde neler yaşandığı ve süreçteki hangi faktörlerin psikoterapinin başarısını artırmada önemli olduğudur (süreç ve sonuç-süreç).

Bu yılları takip eden 50'lerin ortası ve 80'lerin başına kadarki dönemde, psikoterapinin etkinliğini kanıtlamaya yönelik çalışmalar çoğunlukla tedavi ve kontrol gruplarının karşılaştırıldığı yarı-deneysel ya da psikoterapi ortamının simülasyonunu içeren analog desenlerden tek denekli deneyler, meta-analiz ve seçkisizleştirilmiş kontrollü çalışmalara (randomized controlled trial) doğru uzanmıştır [(örn., Wallerstein'ın (1989) Menninger Psikoterapi Projesi)]. Bu çalışmalarda terapist ve danışan özelliklerinin, teknik ve terapi modellerinin psikoterapinin etkinliğini belirlemedeki rolünün, belirli sorun alanları ve bozukluklar için hangi yaklaşımların en işe yarar yöntemler olduğunun ve pek çok yönelim için ortak olan değişim mekanizmalarının belirlenmesi çabaları söz konusu olmuştur. Psikoterapi tekniği açısından bakıldığında ise standart hale getirilmiş, müdahale basamaklarının önceden belirlendiği, sorun çözme odaklı yaklaşımlar bahsedilen 
çalışmalarla kol kola gelişme göstermiştir (Hunsley ve Lee, 2010). Gerek odaklanılan konuların gerekse yöntemlerin çeşitlendiği bu dönemde kontrollü deneysel prensiplere dayalı bulguların psikoterapi odalarının gerçekliğinden uzaklaşmış olması, çoğunlukla araştırmacı ya da terapistlerin bildirimlerine dayalı ölçümler, tek tip danışan ya da terapist varsayımı, toplumsal kimi grupların araştırmaların dışında kalışı ve sağlık sistemlerinin gerekliliklerinin araştırmalar üzerindeki etkileri eleştirilmiştir (Thompson ve Harper, 2012). Bu eleştiriler hem bu dönemde yeni araştırma olasılıklarının düşünülmesine firsat vermiş hem de 1984 'ten günümüze uzanan son dönemdeki yeni bakış açılarının temelini oluşturmuştur (Braakmann, 2015).

Yaklaşık olarak son 40 yılı kapsayan dönem, sosyal bilimlerin genelinde de pozitivist görüşe karşı eleştirel bir duruş sergileyen, temelde post-pozitivist, inşacı ve eleştirel kuramlardan beslenen bir paradigma değişimine tanıklık etmiştir (Creswell, 2013; Kuş, 2007). Bu değişim nicel yöntemlerin tekrar tekrar gözden geçirilmesi ve geliştirilmesiyle sonuçlanmanın yanı sıra, nitel araştırma yöntemlerine hız kazandırmış ve incelenen araştırma sorularına dair bireylerin zihnindeki öznel anlamları ön plana çıkarmıştır. Bu anlamlandırma sürecinin kişilerarası etkileşimin detaylarıyla ve dil ile bağlamın özellikleriyle yakından ilişkili olduğunun altı çizilmiştir (Arkonaç, 2014). Daha önce de belirtildiği gibi, Braakmann (2015) bu değişimi psikoterapi araştırmaları açısından temelde inşacı-yorumsamacı bir çerçevede ele almaktadır. Psikoterapi sürecinde terapist ve danışan arasındaki iletişim, bu iletişimin nelerden oluştuğu ve nasıl gerçekleştirildiği, iletişimin hangi bağlamda gerçekleştiği, terapötik etkilerin nasıl elde edildiği, bireylerin bu değişimleri kendilerinin nasıl değerlendirdiği gibi sorular ile psikoterapinin karmaşık yapısı ve doğal ortamında olan bitenler anlaşılmaya çalışılmıştır. Psikoterapinin etkinliğine dair araştırmalarda istatistiksel anlamlılığın yerini klinik düzeyde anlamlılık; tanı ve belirtilere dayalı değerlendirmelerin yerini ise duygu düzenleme, bağlanma, kişilik yapısı gibi tanılar-üstü psikolojik süreçlerin değerlendirilmesi almıştır (Knox ve Lutz, 2014). Bu dönemde psikoterapi açısından da standardize yöntemlerin katı şekilde uygulanmasındansa kişiye özgü şekilde düzenlenmesinin önemsendiği, terapistin tamamen yansız ve nesnel olduğu fikrinden oldukça uzaklaşıldığ şasına dayalı özneler arası süreçleri anlamayı hedefleyen bütüncül yaklaşımlar benimsenmiştir (Fox, Prilleltensky ve Austin, 2009). Bu bakış açılarını yansıtması açısından, Grzanka ve Miles'ın (2016) psikoterapi eğitiminde cinsel yönelim ile ilgili konular ele alınırken baskın olan söylemleri incelediği çalışma örnek gösterilebilir. 
Türkiye'de gerçekleştirilen psikoterapi çalışmalarında da son yıllarda gerek sayı gerekse incelenen konular açısından her geçen gün artan bir çeşitlilik göze çarpmaktadır. Öyle ki bu derlemenin hazırlandığı tarihte Hacettepe Üniversitesi, İstanbul Bilgi Üniversitesi, İstanbul Arel Üniversitesi, Şema Terapi Enstitüsü ve İstanbul Şehir Üniversitesi'nde özellikle bu alanda çalışmalar yapan psikoterapi araştırması laboratuvarları bulunduğu görülmüştür. Bu laboratuvarlarda ve farklı pek çok üniversitenin psikoloji, psikiyatri, psikolojik danışma, hemşirelik, güzel sanatlar gibi bölümlerinde gerçekleştirilmiş nicel verilere dayalı psikoterapi çalışmalarına rastlamak mümkün olduğu gibi, anlam-temelli paradigma çerçevesinde tasarlanan araştırmaların da hızla artmakta olduğu gözlemlenebilir. Emil Öğünç ve Eren’in (2012) “ön test-son test, kontrol gruplu desende, tek kör deneysel bir çalışma" (s. 32) olarak tanımladıkları, psikodinamik yönelimli bir grup terapisi sürecini incelemeyi amaçladıkları araştırmaları pozitivist prensiplere dayalı bir örnek olarak düşünülebilir. Anlam-temelli çalışmalar arasında, Baltacı ve Gençöz'ün (2019) madde bağımlılığı odaklı bir psikoterapi sürecini Lacanyen söylem analizi ile incelemesi ele alınabilir. Gülüm, Soygüt ve Safran'1n (2018) terapötik ittifak ve psikoterapinin yarıda bırakılması ile ilgili çalışması ise hem nicel hem de nitel verilerin analizine dayalı karma yöntemli bir araştırma olarak karşımıza çıkmaktadir.

Özetle, psikoterapi araştırmaları için psikoloji bilgisi ve psikoterapi yaklaşımlarının gelişimiyle kol kola ilerleyen, bilimsel paradigma değişimleriyle paralel şekilde gelişen ve değişen bir tarihsellikten bahsedilebilir. Daha açık ifade etmek gerekirse, psikoterapinin işe yararlılığı ve süreç boyunca hangi faktörlerin etkili olduğu anlaşılırken neden-sonuç ilişkileri kurmanın yeterli olmadığı ve "nasıl” sorusunun günden güne önem kazandığ1 görülmektedir. Dolayısıyla psikoterapiyi öznel ve bu öznelliğin danışan ve terapist etkileşiminde gözlenebilen öznelerarası bir süreç olarak detaylı şekilde incelemenin yollarının da arandığı bir dönemeç söz konusu gibi görünmektedir. Konuşma çözümlemesinin psikoterapi araştırmaları içindeki konumunu ise tam da bu sözü edilen dönemeçte, yani nitel paradigma içinde değerlendirmek mümkündür.

\section{Konuşma Çözümlemesi Nedir ve Psikoterapide Ne Tür Soruları Yanıtlamayı Amaçlar?}

Psikoterapi araştırmaları kapsamında anlam temelli yaklaşımlar çok çeşitli araştırma yöntemlerine başvurmaktadır. Yukarıda da yer yer örnekleri verilen bu çalışmaların ağırlıklı olarak süreç araştırmaları olduğu söylenebilir (Bkz., Gülüm ve ark., 2018). Sü- 
reç araştırmalarının ağırlıkta oluşu nitel yöntemlerin psikoterapiyi tüm detaylarıyla adeta mercek altına alması ve "ne", "nasıl", "neden" sorularına belirli bir bağlamda ve zamansallık içinde yanıt bulmayı amaçlıyor olduğu gerçeği düşünüldüğünde oldukça anlaşılır görünmektedir.

Kullanılan araştırma yöntemleri açısından bakıldığında psikoterapi araştırmalarında en bilinen ve yaygın olarak kullanılan nitel yöntemler tematik analiz, gömülü kuram, metafor analizi, anlatı analizi, söylem analizi, yorumlayıcı fenomenolojik analiz, Q metodu ve KÇ olarak sıralanabilir (Harper ve Thompson, 2012; Mörtl ve Gelo, 2015). Psikoterapi araştırmaları için bu yöntemlerin birbirinden keskin çizgilerle ayrıştığını söylemek bütünüyle doğru olmamakla birlikte, tematik analiz ve yorumlayıcı fenomenolojik analiz gibi yaklaşımlar psikoterapiyle ilişkili deneyimlerin, tutumların, temsillerin hangi temalar ya da kategoriler etrafinda şekillendiğini ortaya koymakta daha sıklıkla başvurulan yöntemler olarak görülmektedir (Clarke ve Braun, 2018; Larkin ve Thompson, 2012). Q metodu ise bu gibi konuları bireylerin deneyimlerine dair fikirlerini ve tutumlarını önceden belirlenmiş kategoriler çerçevesinde değerlendirmek yoluyla anlamayı hedeflemektedir (Ablon, Levy ve Smith-Hansen, 2011). Gömülü kuram da benzer şekilde psikoterapiyi ilgilendiren birtakım kavramları yakından incelemekte, ancak bunu kendine özgü şekilde tümevarımsal bir yaklaşımla ve bir kuram geliştirme amacıyla yapmaktadır (West, 2001). Anlatı ve metafor analizi ise ağırlıklı olarak psikoterapi boyunca değişen anlamlar yoluyla süreci değerlendirmek için güçlü yaklaşımlar olarak karşımıza çıkmaktadır (Gonçalves ve Angus, 2017; Levitt, Korman ve Angus, 2000). Son olarak araştırmalarında söylem analizinden faydalanan araştırmacılar psikoterapiyi bir sosyal eylem olarak görmekte, psikoterapideki etkileşimin ve psikoterapiyle ilgili söylemlerin bireylerin içinde bulunduğu sosyo-kültürel sistemler ve birbirine göre konum alış pratikleri açısından çözümlemesine başvurmaktadır (Avdi ve Georgaca, 2007).

KÇ yukarıda sıralanan yöntemlerle ortak şekilde bireylere özgü psikoterapi deneyimini yakından anlama amacı taşımakta; psikoterapi pratiğinin bir sosyal eylem olarak kabul edilmesi gibi kimi varsayım ve yaklaşımlar açısından onlarla paralellikler göstermektedir. Ancak, Georgaca ve Avdi (2009) psikoterapi araştırmalarında söylem analizi, anlatı analizi ve KÇ’yi karşılaştırdıkları makalelerinde KÇ’nin diğer anlam temelli yöntemlere kıyasla en güçlü ve öne çıkan özelliğinin psikoterapiyi uygulandığı anda, bir diğer deyişle şimdi ve burada, sözel olan ve olmayan etkileşim araçları yoluyla incele- 
me imkanı sunması olduğuna işaret etmişlerdir. Bunun yanı sıra, KÇ’nin bu yazının devamında daha detaylı şekilde ele alınacağı üzere hem bir yöntem olarak kendine özgü prensipleriyle hem de psikoterapi araştırmalarında ortaya koyduğu yenilikçi araştırma sorularıyla alana özgün katkıları da vardır. Bu katkıları anlayabilmek için öncelikli olarak KÇ'nin temel varsayımları ve yöntemsel ilkelerini yakından incelemekte fayda görülmektedir.

KÇ bir araştırma yöntemi olarak esasında yalnızca psikoterapi araştırmalarında kullanılmamaktadır. Sert, Balaman, Daşkın, Büyükgüzel ve Ergül (2015a) KÇ ilkelerini detaylı şekilde açıkladıkları, ilgili alan yazına dair önemli bulguları derledikleri ve KÇ ile ilişkili temel kavramları Türkçeye kazandırdıkları makalelerinde uygulamalı dilbilim, sosyoloji, iletişim, tıp, psikoloji, eğitim gibi pek çok farklı alanda KÇ kullanılarak gerçekleştirilen çalışma örneklerinden söz etmektedirler ${ }^{1}$. Rapley (2012) KÇ’nin gelişiminde üç önemli bilim insanının oynadığı rolün altını çizmektedir. Bu isimler Goffman, Garfinkel ve Sacks’tır. Ona göre, Goffman'ın sosyal etkileşim üzerine sosyoloji alanındaki çalışmalarından yola çıkan Garfinkel budunyöntembilimi (ethnomethodology) geliştirmiştir (Rapley, 2012). Garfinkel'in (1967) budunyöntembilim anlayışında öne çıkan düşüncelerden biri insan davranışı ve toplumsal düzene dair öğeleri anlamanın, sıradan insanların kendilerine özgü gündelik etkileşimleri ve ortak akla dayalı bilgilerini incelemekten geçtiğidir. Bu düşünceden yola çıkılarak günlük konuşmalar birer sosyal eylem olarak kabul edilmiş, Sacks, Schegloff ve Jefferson'ın (1974) intihar yardım hatlarına gelen aramalarda gerçekleştirilen karşılıklı konuşmaları incelediği çalışmaları ile KÇ'nin ilk örneği alan yazına kazandırılmıştır. Psikoloji alanındaki çalışmaların gelişimi düşünüldüğünde ise Sacks'ın (1992) KÇ üzerine yayınladığı ilk derslerinden itibaren bireylerin zihinsel süreçleri ve sosyal etkileşim arasındaki ilişki ile ilgili fikirlerin ortaya çıktığı söylenebilir. Potter ve Edwards (2013) KÇ’nin psikolojideki gelişimini kapsamlı şekilde gözden geçirmiştir ve psikolojideki ilk çalışmaların düşünme ve anlama gibi bilişsel süreçleri ele aldığını, bu çalışmalarda söz konusu süreçlerin nasıl değerlendirildiğinin ve sosyal etkileşim içinde nasıl ortaya konduğunun incelediğini ifade etmişlerdir. Doksanlı yıllarla birlikte ise alan yazının bilgi işleme, sosyal biliş, tutumlar gibi bireysel ve sosyal psikolojik olguları öznelerarası etkileşim içinde ele almaya doğru evrildiğini belirtmişlerdir.

1 Bu yazının ve farklı disiplinlerden Türkçe KÇ çalışmalarının yer aldığı 2015 tarihli özel dergi sayısı için bkz. Mersin Üniversitesi Dil ve Edebiyat Dergisi, Cilt 12, Say1 2. 
Günümüzde en genel hatlarıyla KÇ, doğal ortamında gerçekleşen konuşmaları incelemek olarak tanımlanmaktadır (Ten Have, 2007). Bu incelemeyi gerçekleştirmekteki en temel amaç “Konuşurken ne yaparız?”, “Konuşmamızı ne şekilde düzenleriz?”, “Bir diyalog içinde konuşmacılar nasıl eşgüdüm içinde olurlar?” ve "Konuşmanın sosyal süreçlerdeki rolü nedir?” sorularının cevabını bulmaktır (Hutchby ve Wooffitt, 2008, s. 1). Bunun için, KÇ çalışmalarında incelenen konuşmalara ait ses ya da video kayıtları alınarak elde edilmiş ham veri, etkileşimin niteliklerini en üst düzeyde koruyacak şekilde, gerçeğine en yakın haliyle bir takım çeviriyazı (transcription) simgeleri kullanılarak yazıya dökülmektedir². Jefferson'ın (2004) çeviriyazı sisteminde olduğu gibi bu durum, konuşma içindeki ses yükselmesi/alçalması, duraksama, nefes alma, üst üste binen konuşmalar gibi etkileşimsel öğeleri analize dahil etmeyi sağlamaktadır. Video kayıtları KÇ çalışmalarında gittikçe artarak kullanılmaktadır. Böylece KÇ, Mondada'nın (2019) vurguladığı gibi sosyal etkileşim alanındaki araştırmalar için aranan bir özellik olan çokkipliliği (multimodality) sağlayabilir hale gelmektedir. Çokkiplilik kavramını kısaca açmak gerekirse, bir analizde birden fazla veri kaynağının kullanılmasından söz edildiği anlaşılabilir. KÇ için düşünüldüğünde ise konuşmaya eşlik eden postür, mimik, bakış gibi öğeler çözümlemeye dahil edilerek konuşmacıların birbirlerinin sözel olan ve olmayan tepkilerini nasıl anlamlandırdıklarına dair daha fazla bilgi edinilebilmektedir (Mondada, 2019). Video kayıtlarındaki bu öğelerin de çeviriyazıda nasıl temsil edilebileceği ile ilgili bir kaynak olarak Atkinson ve Heritage'a (1999) başvurulmaktadir.

KÇ çalışmalarında, araştırmacıların hangi tür konuşmaları inceleyebileceği ile ilgili herhangi bir kısıt bulunmamaktadır. Örneğin, Haakana (2010) bir mağazada tesadüfen gerçekleşen karşılaşmalar ve günlük telefon görüşmelerinde gülme ile gülümsemenin bir arada kullanıldığı etkileşimler üzerine çalışmıştır. Bu çalışmanın bulgularından biri gülmenin içinde bulunulan durumun gülünç olduğu kadar, hassas ya da sıkıntılı olduğunu da onaylama işlevi taşıdığı olmuştur. Stafford, Hutchby, Karim ve O’Reilly (2016) ise çocukların psikiyatrik değerlendirmelerinde uzman ve çocuk arasındaki konuşmalara ait ses kayıtlarını incelemiş, konuşmaların çocukların çoğunlukla neden psikiyatri kliniğinde olduklarını bilmediklerini gösterdiği sonucuna varmışlardır. Her iki araştırma da KÇ'den faydalanmış olsa da, incelenen konuşmaların bağlamları ve amaçları arasın-

2 KÇ araştırmalarında ses kayıtlarının yazıya dökümünde yaygın olarak kullanılan çeviri yazı simgeleri için bkz. Jefferson, 2004. 
daki fark KÇ’nin nasıl yürütüleceği ile ilgili bir ayrım yapmayı gerektirmektedir. Örneklendirilen ilk araştırma, saf (pure) KÇ diyebileceğimiz, tamamen gündelik ve kendiliğinden gerçekleşen konuşmaların incelendiği bir çalışmadır. Saf KÇ herhangi bir kurumsal ortamda gerçekleşmeyen, gündelik konuşmaların yalnızca konuşma düzeninin ve konuşmada kullanılan dilsel araçların anlaşılabilmesi amacıyla incelendiği çalışmaların genel adıdır (Heritage, 1998). İkinci araştırma ise kurumsal bir ortamda gerçekleşen, konuşmacıların rollerinin (doktor-hasta) ve etkileşimin yazılı olan ve olmayan kurallarının önceden belirlendiği bir etkileşimi ele almaktadır. Burada amaçlanan yalnızca doktor ve hastaların kullandıkları dilsel araçları belirlemek değil, bu araçların mesleki bir uygulamanın nasıl yürütülmesi gerektiği ile ilgili çıkarımlarını da anlamaktır. Sacks ve arkadaşlarının (1974) intihar yardım hatlarına gelen aramalar üzerine çalışmasını da bu anlamda düşünmek mümkündür. Bu tür bir araştırmanın hem kurumsal bir çatı altında yardım etmekle sorumlu bir uzman ve ona danışan kişinin etkileşimine dayanması, hem de uzmanların telefona nasıl cevap verdiklerinin danışanın yardım hattından ne şekilde yararlandıklarını belirlemek açısından yardım hattı uygulamalarına yol gösterici olması beklenebilir. Medya programları, okullar, hastaneler ve psikoterapi odaları gibi ortamlarda etkileşimlerin analizi söz konusu olduğunda uygulamalı (applied) ya da kurumsal (institutional) KÇ olarak adlandırılmaktadır ${ }^{3}$. Bilindiği üzere psikoterapi de tıpkı psikiyatrist-hasta görüşmeleri ve intihar yardım hatlarında olduğu gibi danışan ve psikoterapistlerin rollerinin ve profesyonel çalışma çerçevesinin önceden belirlenmiş olduğu bir sosyal etkileşim türüdür (Perakyla, 2013). Bu başlığın altında detaylı şekilde değinileceği üzere KÇ çalışmaları sonucunda psikoterapi pratiğine yön verecek pek çok mesleki çıkarım yapmak mümkündür.

İyi bir KÇ araştırmasında benimsenen temel ilkeler ve bu ilkelerin üzerine kurulu olduğu bazı epistemolojik varsayımlar bulunmaktadır. Sert ve arkadaşlarının (2015a) özetlediği gibi KÇ’nin belirli ilkeler çerçevesinde yürütülmesi beklenmektedir. Buna göre etkileşim boyunca karşılıklı anlaşılabilirliğin nasıl bir sistematik düzen (söz sırası alma, onarım vb.) içinde gerçekleştiği ve hem bağlamı şekillendiren hem de bağlam tarafından şekillenen etkileşimsel katkıların neler olduğu doğal etkileşimlerden edinilen veriye dayalı olarak ve konuşmacıların içeriden bakış açısını (emic perspective) yansıtır şekilde ayrıntılı olarak çözümlenmelidir.

3 Türkçe dilinde kurumsal KÇ örnekleri için bkz. Büyükgüzel ve Gül, 2015; Sert ve Balaman, 2015; Sert, Bozbıyık, Elçin ve Turan, 2015b. 
Bu ilkeler konuşmanın eylem yönelimli oluşu, konuşmanın belli düzen ve kurallarla gerçekleştirilmesi, bireylerin kültürün pasif bir alıcısı olmamaları, budunyöntembilimsel kayıtsızlık ve veriye dayalı yorumlama şeklinde sıralanabilecek temel epistemolojik varsayımlara dayalıdır (Rapley, 2012). İlk varsayıma göre konuşmadaki kişiler konuşmayı belli şekillerde tasarlayarak bir şey yapar, belirli amaçları gerçekleştirir ya da dünyaya dair anlamlar oluştururlar. Bunun için karşılıklı anlaşılabilirliğin gerçekleşmesi hedeflenir (Rapley, 2012). Psikoterapi içinde geçen konuşmalardan bir örnek vermek gerekirse Yao ve Ma (2017) danışanların sessiz kalarak, sorulan sorulara cevap vermeyerek ya da aşırı konuşarak direnç gösterdikleri, terapistlerin de bu eylemlere karşı daha fazla soru sorarak direncin üstesinden gelmeye çalıştıkları sonucuna varmıştır. Karşılık1 konuşmanın yukarıda tarif edildiği şekildeki tasarımı direnç ve direncin aşılması eylemlerinin hayata geçirilmesini sağlamıştır.

İkinci varsayım karşılıklı konuşmaların bir sıralı düzen içinde gerçekleştirilmesi yoluyla süreklilik arz ettiğini ima eder. Konuşmacılar sırayla ve birbirini tamamlar şekilde konuşurlar (Rapley, 2012). Sacks’ın (1992) 1964-1972 yılları arasında yürüttüğü KÇ ile ilgili dersleri ile Schegloff'un (2007) çalışmaları konuşma düzeninin hangi özelliklerinin çözümlenmesi gerektiğine dair önemli kılavuz kaynaklardır. Bu kaynaklar 1şı̆̆ında günümüzde yaygın olan, karşılıklı konuşmanın sıralı yapısının basit konuşma üniteleri olarak tanımlanan söz sırası almadan (turn taking) gitgide karmaşıklaşan şekilde söz s1rası tasarımı (turn design), onarım (repair) ve dizi düzenine (sequence organization) uzanan yelpazede incelenmesidir. Yao ve Ma’nın (2017) araştırması bu kapsamda tekrar düşünülürse, sorulara cevap verilmemesi karşılıklı konuşmalarda dizi düzeninin soru-cevap çifti şeklinde devam etmesi varsayımını ihlal etmektedir.

Bireylerin kültürün pasif bir alıcısı olmamaları, budunyöntembilimsel kayıtsızlık ve veriye dayalı yorumlama konuları birey-sosyal yapı etkileşimine dair KÇ’nin nasıl bir duruşu olduğuyla ilişkilidir. Buna göre birey ve içinde bulunduğu kültür arasında bir ilişki vardır ve kurumsal etkileşim içinde, bireylerin edindiği kimi sosyal roller söz konusu olabilir (Rapley, 2012). Nitekim uygulamalı KÇ çalışmalarında sıra alış ya da dizi düzeni tasarımı gibi öğelere ek olarak, bu tasarımlar gerçekleşirken meydana çıkan sözcük seçimi (lexical choice) ile epistemolojik ve diğer asimetri şekillerinin (epistemological and other forms of asymmetry) çözümlenmesi bu etkilerin varlığının kabul edildiğinin göstergesidir (Heritage, 1998). Ancak bu ilişki ve etkileşimlerde edinilen roller tek yönlü şekilde, bireylerin bilgi ve kontrolünün tamamen dişında ger- 
çekleşmez; bireylerin konuşmalarında belirli şekilde etkileşime girerek kendilerinin de bizzat üreticisi oldukları süreçler olarak görülür. KÇ bağlamında düşünüldüğünde bu aynı zamanda bireylerin özneler arası düzlemde bu sosyal rolleri icra edebilecekleri ancak bunun verili ya da atanmış şekilde analiz edilmediği anlamına gelmektedir. $\mathrm{Bu}$ nedenle, araştırmacı da bu anlamdaki kuramsal varsayımlarını paranteze alarak (bracketing) çözümlemelerini gerçekleştirmelidir (Sert ve ark., 2015a). Söylem analizi gibi yöntemlerde ise bir takım kuramsal bakış açılarıyla bir analiz ve yorumlama yapılması mümkündür (Arkonaç, 2014). Stafford ve arkadaşlarının (2016) çocuk hasta-psikiyatrist etkileşimlerine dayalı çalışması bu varsayımlar açısından tekrar düşünüldüğünde çocuklar neden bir uzmanla görüştüklerini bilmezken psikiyatristler hem bu konuşmanın neden gerçekleştiğine hem de çocukların psikolojik durumuna dair bir takım fikirlere sahip görünmektedir. $\mathrm{Bu}$, çocuk hastalar ve uzmanlar arasında bilgiye ve konuşmayı düzenleme gücüne sahip olma anlamında bir asimetri olduğunun göstergesi olarak düşünülebilir. Bir diğer deyişle, konuşma içinde herhangi bir eylemi gerçekleştirme hakkının kime ait olduğu ya da uygun olan rollerin ne olduğu konuşma tasarımı üzerinde belirleyici olmaktadır. Yeni bir sırayı kimin başlattı̆̆ı, bunu ne şekilde yaptığ 1 (örn., kendinin söz alması ya da karşısındakinin ona söz vermesi), kimin hangi tür eylemleri gerçekleştirmesinin beklendiği (örn., doktorun soru sorması, hastanın cevap vermesi) gibi sorular çözümlemelere dahil edilmektedir; fakat psikiyatrist-çocuk hasta konuşması içinde kanıt olarak sunulamayan herhangi bir kuramsal önermeye dayalı çıkarım söz konusu olmamaktadır. Sert ve arkadaşlarının (2015a) özetlediği gibi “... bu yöntemi kullanırken güç, cinsiyet, ırk ve toplumsal konum gibi bağlamsal etkenler sadece etkileşimin ayrıntılarında kanıtlanabildiği sürece dikkate alınır." (s. 6).

Psikoterapi araştırmalarında KÇ kullanılarak yapılan çalışmaların genel eğilimine, hangi konuları ele almış olduğuna ve ne yöne doğru geliştiğine bakıldığında psikoterapinin pek çok farklı yönüne odaklanıldığını gözlemlemek mümkündür. Öncelikle şunu belirtmekte fayda var ki, KÇ çalışmaları psikoterapide bulunan bireylere dair duygusal ya da bilişsel yapılar gibi zihinsel süreçlerle ilgili çıkarımda bulunma amacı gütmediği gibi birincil olarak psikoterapinin başarılı olup olmadığını değerlendirmemektedir (Rapley, 2012). Ancak psikoterapi çalışmalarında ilk KÇ örneklerinden itibaren psikoterapi pratiğine dair oldukça zenginleştirici çıkarımlar yapıldığı söylenebilir (örn., Heritage ve Watson, 1979; Madill, Widdicombe ve Barkham, 2001; Vehvilainen, 2003). 
Psikoterapiyi veri olarak kullanan ve etkileşimin mikro düzeydeki niteliklerini araştıran ilk çalışmalar dilbilim alanından Pittenger, Hockett ve Danehy'in (1960) genç bir şizofreni hastası ile psikiyatristinin değerlendirme amaçlı görüşmelerini ve bir psikiyatrist olan Scheflen'in (1973) bir şizofreni hastası ve annesiyle gerçekleştirilen 10'ar seanslık iki psikoterapi sürecini incelemesiyle başlamıştır. Bu çalışmalar psikoterapide konuşmanın hangi araçlarla ve nasıl gerçekleştirildiğini anlama çabalarının başlangıcı olarak sayılmaktadır (Perakyla ve ark., 2008). KÇ kullanılarak yürütülen ilk psikoterapi çalışması ise Davis'in (1986) psikoterapide problemlerin yeniden kavramsallaştırılması (reformulation) üzerine gerçekleştirdiği çözümleme olarak karşımıza çıkmaktadır.

Perakyla ve arkadaşları (2008) psikoterapide KÇ çalışmalarının gelişiminin sistematik şekilde gerçekleşmediğine işaret etmektedirler. Daha ziyade, çeşitli dallanıp budaklanmalar ve farklı konu ve araştırma hedeflerinin kesişimi söz konusudur. İlerleyen yıllarda Perakyla (2013) bu alandaki araştırma eğilimlerini psikoterapide yapılan yorumlar gibi teknikleri içeren temel pratikler ve direnç gibi deneyimlerin araştırıldı̆̆ 1 ilişkisel yönler olarak ikiye ayırmıştır. Bu tarihten sonraki araştırmalarla birlikte düşünülerek bir güncelleme yapmak ve araştırmaları belli ana başlıklar altında ele almak gerekirse, yürütülen çalışmaların çerçevesini oluşturan konular bu yazıda terapötik müdahaleler, terapi ilişkisine dair öğeler ve psikoterapinin etkileri olarak sınıflandırılmıştır.

\section{Terapötik Müdahale Çalışmaları}

Terapötik müdahale çalışmaları Perakyla'nın (2013) temel pratikler olarak da adlandırdığı kavramsallaştırmalar, yorumlar, sorular gibi psikoterapi hedeflerini gerçekleştirmeye yönelik psikoterapi tekniklerini ve terapistlik becerilerini konu almaktadır. Psikoterapide kullanılan terapötik müdahalelerin nasıl gerçekleştirildiğiyle ilgili çalışmaların önemli bir kısmı Davis'in (1986) ilk araştırmasıyla paralel şekilde danışan problemlerine dair kavramsallaştırmanın (formulation) konuşma içindeki işlev ve anlamlarına odaklanmıştır. Heritage ve Watson (1979) kavramsallaştırmanın diğer etkileşim biçimlerinden nasıl ayrıştığını detaylı şekilde incelemiş ve danışanların dile getirdiklerini özetleme, anlamlandırma ve farklı içerikleri ilişkilendirme gibi nitelikler belirlemişlerdir. Vehvilainen (2003) ayrıca kavramsallaştırma yoluyla terapistlerin danışanlara yeni bir kavrayış kazandırabildikleri sonucuna varmıştır. Bunun için terapistler danışanların söylediklerinin bilinçdışı anlamları ve duygusal içeriklerine atıf yapma gibi konuşma araçları kullanmışlardır. Bir başka çalışmada ise Hutchby (2005) terapistlerin soruları ve danışanların cevaplarının ardından gelen terapist kavramsallaştırmalarını ak- 
tif dinlemenin bir göstergesi olarak ele almıştır. Antaki, Barnes ve Leudar (2005) tanı amaçlı kavramsallaştırmaları incelemiş ve danışan problemlerini değerlendirirken "yani” ya da "... dediğinizi anlıyorum" gibi ifadelerin doğrudan soru sormaya kıyasla avantajlarını tartışmışlardır. Weiste ve Perakyla (2013) ise terapide farklı amaçlara hizmet eden dört çeşit kavramsallaştırma bulunduğunu, bunların terapist ve danışanın aynı şeyi anlayıp anlamadığını doğrulama ya da kimi duygusal tepkileri açığa çıkarma gibi işlevler taşıyabileceğini ortaya koymuştur.

Yapılan KÇ çalışmaları kavramsallaştırmaların çoğunlukla yorumlarla desteklendiğini göstermektedir (Perakyla ve Vehvilainen, 2003; Vehvilainen, 2008; Weiste, Voutilainen ve Perakyla, 2016). Yorumlar da kavramsallaştırma gibi danışanın psikoterapiye getirdiklerine yönelik anlamlandırma ve çıkarımlardır. Bercelli, Rossano ve Viaro (2008) bu iki müdahale arasında bir ayrım yapmakta ve kavramsallaştırmaların danışanın, yorumların ise ağırlıklı olarak terapistin bakış açısını ortaya koyma işlevi taşıdığını vurgulamaktadırlar. Zira 100'e yakın psikoterapi seansını inceledikleri araştırmalarında terapistlerin yorumlarını iletirken sözcük seçimlerinde "bence”, “... düşünüyorum”, "belki de ...” gibi ifadeler ön plana çıkmaktadır. Danışanların tepkilerine bakıldığında ise alındılama işareti (acknowledgement token), onaylama, red, genişletme gibi etkileşimsel araçlar gözlemlenmektedir. Yani, danışanlar ya yorumları anladıklarını, kabul ettiklerini ya da reddettiklerini göstermekte ve kabul veya red gerekçelerini açıklamaktadırlar. Her iki durumda da bakış açıları ya da yaşantısal deneyimlerine dair ek bilgiler sundukları görülmektedir (Bercelli ve ark., 2008). Voutilainen, Perakyla ve Ruusuvuori (2010) ise bilişsel-inşacı yaklaşımla yürütülen bir psikoterapi sürecinde duygusal tepkilerin terapistlerce nasıl yorumlandığını anlamayı amaçlamışlardır. Çözümlemeleri, terapistlerin yorumlarına danışanın duyguları$\mathrm{n}$ fark ve kabul etme gibi öğeleri eklediklerini ya da yorumlarını duygusal tepkileri tanır şekilde tasarladıklarını göstermiştir.

Soruların terapötik müdahale amaçlı kullanımı da KÇ araştırmalarını ilgilendiren bir konu olmuştur. McGee, Vento ve Bavelas (2005) psikoterapi etkileşiminde soru-cevap sıralı çiftlerinin bilgi alma ve bilgi vermenin dışında terapötik amaçlarla kullanılabildiğini dile getirmektedirler. Bartesaghi (2009) soruların problemi belirleme, ortaklaşma, kurumsal rolleri (örn., tanı koyma) yerine getirme gibi işlevlerinden söz etmektedir. Daha özelinde, çalışmalar soruların kimi müdahaleleri yaparken yardımcı bir araç olarak kullanıldığını göstermektedir. MacMartin (2008) iyimser soruların danışanların yetkinlik hislerinin artırmayı, Halonen (2008) gizli özne içeren soruların danışanların 
problemleri kabul etmelerini, Speer (2010) ise hipotetik soruların terapistlerin şüphelerini iletmeyi, yüzleştirme yapmayı ve danışana yeni bakış açıları kazandırmayı sağladığını ortaya koymuşlardır.

\section{Terapi İlişkisi ile İlgili Çalışmalar}

Psikoterapi ilişkisi KÇ çalışmalarının bir diğer odak noktası olmuştur. Psikoterapi ilişkisi ya da terapötik ilişki psikoterapi bağlamında birden fazla olguya işaret etmektedir. Bunlardan birincisi psikoterapinin başarısını da yordayan terapötik ittifak, yani danışan ve terapistin olumlu bir bağ kurmaları, terapinin sonunda ulaşmak istedikleri hedefler ve bu hedefleri gerçekleştirirken nelerin yapılması gerektiği ile ilgili fikir birliği içinde olmalarıdır (Bordin, 1979). Ağırlıklı olarak psikodinamik terapilerin ele aldığ1 şekliyle ikinci olgu ise, danışan ve terapistin kurdukları ilişkinin kendine özgü niteliğinin ne olduğudur (Gelso ve Hayes, 2007). İkilinin birbiriyle kurduğu ilişkide ağırlıklı olarak hangi duyguların yer aldığı, hangi rolleri edindikleri gibi konular bu kapsamda düşünülmektedir. Profesyonel ilişkinin sınırları ve nötr olmak gibi terapist tutumlarını içeren terapi çerçevesi ise terapi ilişkisiyle ilgili bir diğer olgudur (Lemma, 2003).

Perakyla (2019) son 10 y1lda empati, duygular, iş birliği gibi konulardaki çalışmaların önemli bir hız kazandığından ve müdahale çalışmalarının sayıca önüne geçtiğinden söz etmektedir. Dolayısıyla terapi çerçevesindense terapötik ittifak ve ilişkinin kendine özgü niteliği çalışmalara daha fazla konu olmuş gibi görünmektedir. İlişki alanındaki çalışmaların gelişimi ilişkisel ya da terapötik ittifak ile ilgili özelliklerin çoğunlukla yapılan müdahaleler bağlamında incelenmesi yönünde bir eğilime işaret etmektedir. Yukarıda değinilen, Voutilainen ve arkadaşlarının (2010) çalışmaları bir terapi tekniği olarak yorumları anlamayı hedeflemiş olsa da duyguların tanınması ve kabul edilmesi empatik bir ilişki kurma anlamında terapötik ittifak ile ilgili çıkarımları da mümkün kılmaktadır. Benzer şekilde, Fitzgerald (2013) empati ve koşulsuz kabul gibi ilişki kalitesini belirleyen etkileşimlerin tek bir sıra alış düzeni içinde değil; uzun, birbirini takip eden dizilerde ve yorumlar, sorular, öykü alma gibi diğer terapist müdahaleleriyle iç içe geçmiş şekilde gözlemlendiğini belirtmiştir.

Terapi iliş̧isine dair KÇ çalışmalarının geneline baktığımızda ortaklık (affiliation), uzlaşma (agreement), işbirliği (collaboration), anlaşmazlık (disagreement), işbirliğinin bozulması (break of collaboration), asimetri, direnç, empati gibi konuların ele alındığı görülmektedir (Antaki, 2008; Cardoso, Pinto ve Ribeiro, 2019; Hutchby, 2005; Madill 
ve ark., 2001; Muntigl ve Horvart, 2014; Sutherland ve Strong, 2011; Weiste ve ark., 2016; Wynn ve Wynn, 2006; Yao ve Ma, 2017). Sessizlik (Cardoso ve ark., 2019; Madill ve ark., 2001), konuyu değiştirme (Madill ve ark., 2001) ya da "bilmiyorum” şeklindeki cevaplar (Antaki, 2008; Hutchby, 2005) ile ilişkinin kesintiye uğrayabildiği ya da KÇ terminolojisiyle dile getirmek gerekirse terapist ve danışanların farklı etkileşimsel eylemleri hedefleyebileceği gösterilmiştir. Bu gibi durumlarda etkileşimin ortaklaşması adına terapistlerin kullandıkları etkileşimsel araçların incelenmesi de psikoterapi uygulamalarına dair önemli ipuçları taşımaktadır. Örneğin, Sutherland ve Strong (2011) aile terapisinde terapötik iş birliğinin nasıl sürdürüldüğünü araştırmıştır. Bulguları, terapistlerin danışanların tercihlerini sorma, uzman rollerini belirsizleştirme ve ön genişletmelerle danışanları yeni konu ve müdahalelere hazırlama gibi farklı amaçlarla etkileşimsel araçları kullandıklarını göstermektedir. Cardoso ve arkadaşlarının (2019) yürüttüğü daha güncel bir çalışmada da terapötik iş birliğinin tekrar kurulduğu ve kurulamadığı etkileşimlerin kendine özgü nitelikleri belirlenmeye çalışılmıştır. Sarı (2019) ise hem terapist hem de danışanların kaçınma örüntülerini incelemiş ve terapötik iş birliğinin sekteye uğradığı durumların fark edilebilmesinin önemine dair çıkarımlarda bulunmuştur.

Psikoterapi ikilisinin kurduğu ilişkiye dair örüntüler ve dinamiklerin de KÇ araştırmalarının konusu olabildiğinden yukarıda söz edilmiştir. Bu anlamda, kuramsal olarak da ilişkisel dinamikler odaklı ve hem psikanalitik hem de psikodinamik yaklaşımlı psikoterapilerin incelenmesi yönünde bir eğilim olduğu söylenebilir. Buchholtz, Spiekermann ve Kachele'nin (2015) KÇ ve metafor analizinden faydalandıkları psikanalitik yönelimli vaka çalışması bu tür çalışmalar arasında en bilineni olarak sayılabilir. Psikoterapi uygulaması ve psikanalitik kurama dair pek çok farklı konuya eğilmekle birlikte, bu çalışma terapist ve danışanın diğerinin aklının içindekileri anlayan ve diğerini takip eden gibi rolleri konuşmalarında nasıl inşa ettiklerini ve yeri geldiğinde bu rolleri nasıl değiştirebildiklerini açığa çıkarmaktadır.

Ülkemizde de Dilekler'in (2018) çalışması aracılığıyla psikoterapide ilişkisel dinamikleri ele alan bir KÇ örneği görülmektedir. Dilekler (2018) terapist ve sadomazoşist kişilik özelliklerine sahip danışanlar arasındaki aktarım ve karşı aktarım dinamiğini incelemiştir. Bu çalışmada psikoterapi ilişkisinde, iş birliği ve işbirliğinin bozulmasına ek olarak işbirliğine dair ikircikli örüntüler (işbirliği ve işbirliğinin bozulmasının birlikte görüldüğü etkileşimler) bulunabileceği gözlemlenmiş ve bunun psikoterapide sadist, 
mazoşist ve sadomazoşist ilişki kurma biçimleri açısından anlamları tartışılmıştır. Aşağıda bu çalışmadan alıntılanmış, psikoterapi ilişkisinde iş birliğinin gözlendiği bir etkileşim örneği ve analizinin bir kısmı sunulmaktadır (Kesitte yer alan çeviriyazı simgeleri ve anlamları için Bkz. Tablo 1).

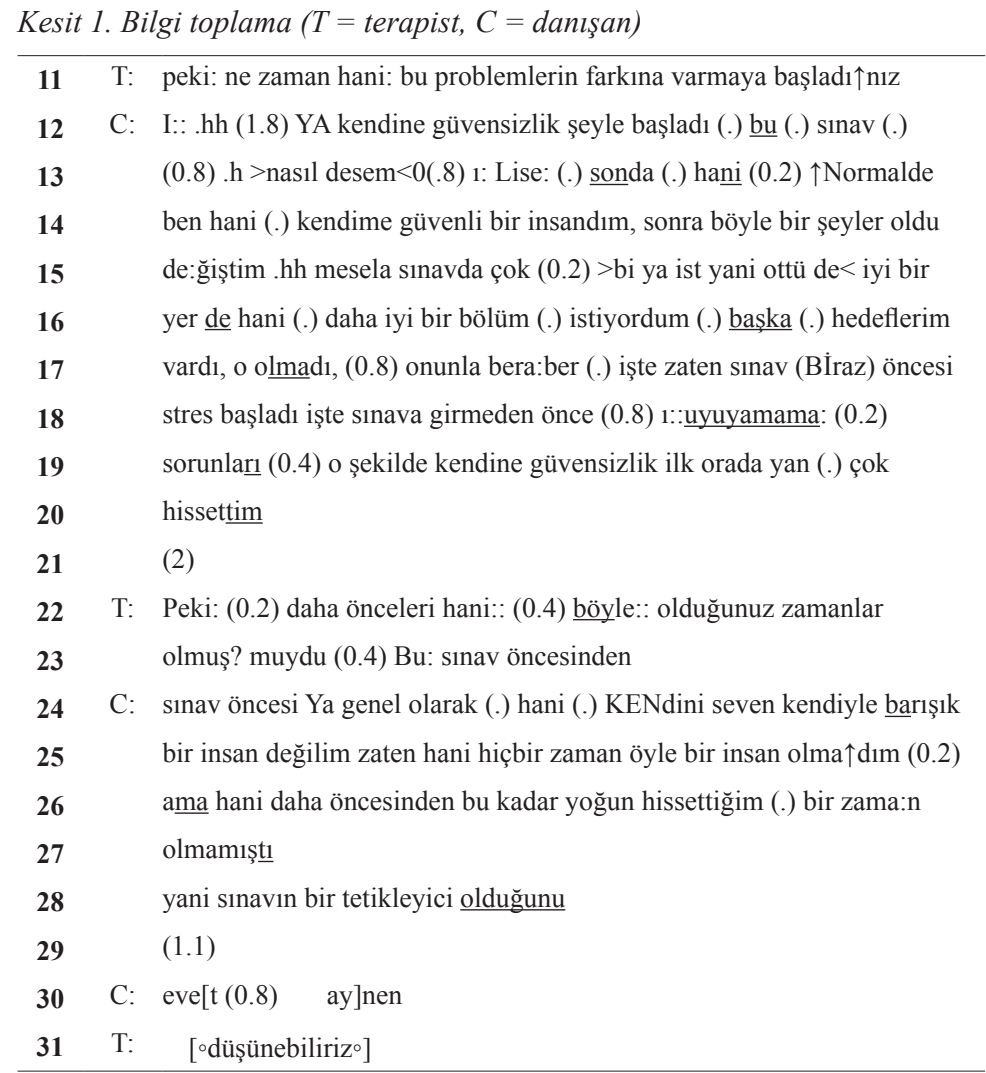

Gösterilen kesitte terapistin danışanın problemlerini ne zaman fark ettiğine dair sorusu ile konuşma başlamaktadır. Danışan ise "I:: .hh" ifadesi ve 1.8 saniyelik kısa bir duraksama ile ikilinin daha önce üzerine konuştukları anlaşılan kendine güvensizlik sorununun lise sonda başladığı yanıtını vermiştir ve bu dönemden önce ve sonrası ile ilgili kendine dair ek bilgiler, stres, uyuyamama gibi diğer sorunlar ile ilgili açıklamalarda bulunmuştur. Bu noktada terapist ve danışanın dizi düzeni tasarımını soru-cevap sıralı çifti şeklinde tasarladıkları görülmektedir. Etkileşimin buraya kadarki kısmında işbirliğine dair pek çok öğeden söz edilebilir. Birincisi terapist yeni bir söz sırası alarak sıralı çiftin ilk kısmını tasarlamış, danışan ise terapistin kendisine atadığı söz sırasını alarak 
soru-cevap çiftinin cevap bölümünü oluşturan bir eylem gerçekleştirerek sıralı çiftin ikinci kısmını oluşturmuştur. Sacks ve arkadaşları (1974) terapistin danışana bir soru yönelterek yaptığı gibi o an konuşanın bir sonraki konuşmacıyı seçmesi yoluyla söz s1rasını paylaşabileceğini söylemektedir. Danışan ise hem kendisine atanan söz sırasını alarak hem de terapistin sorusuyla gerçekleştirmeyi amaçladığı sosyal eyleme (bilgi toplamaya) uygun şekilde, KÇ alan yazınında yeğlenen olarak adlandırılan (Sert ve ark., 2015a) bir cevap vermiştir. Ayrıca danışanın aldığı söz sırası içindeki söz sırası oluşturma birimleri yeni bilgiler içermektedir. Bu durum, Bercelli ve arkadaşlarının (2008) psikoterapi üzerine yaptığ ç̧alışmada da bir onaylama olarak ele alınmıştır. Bu etkileşim için de danışanın ek açıklamalar getirmesinin etkileşimdeki işbirliğini artırmak açısından benzer bir işlev taşıdığı anlaşılmaktadır. Yirmi iki ve 27. satırlar arasında da benzer şekilde bilgi toplama amacına yönelik bir etkileşim gerçekleştiği görülmektedir. Terapist özellikle 22. satırda 11. satırda yönelttiği ilk soruyla ilgili daha fazla bilgi alma ve danışanın etkileşime katılımını derinleştirme amaçlı olduğu anlaşılan bir art-genişletme (post-expansion) tercih etmektedir.

Tablo 1. Kesit 1'de Yer Alan Çeviri Yazı Simgeleri ve Anlamları

\begin{tabular}{|c|c|}
\hline Simge & Anlamı \\
\hline [] & $\begin{array}{l}\text { Örtüşme } \\
\quad[\text { örtüşmenin başlangıç, ] ise bitiş noktasını gösterir. }\end{array}$ \\
\hline (.) & $\begin{array}{l}\text { Anlık duraklama } \\
\quad 0.2 \text { saniye ve daha kısa süreli duraklamaları gösterir. }\end{array}$ \\
\hline (0.9) & $\begin{array}{l}\text { Duraklamanın uzunluğu } \\
\quad \text { Örnekteki gibi bir sayıyla ifade edildiğinde konuşma içindeki duraklamanın süresini ifade eder. }\end{array}$ \\
\hline$\underline{a b c}$ & $\begin{array}{l}\text { Vurgu } \\
\quad \text { Alt1 çizili konuşma bölümünün vurgulanarak söylendiğini gösterir. }\end{array}$ \\
\hline$\circ \circ$ & $\begin{array}{l}\text { Düşük ses } \\
\quad \text { İşaretler arasında bulunan konuşmanın yumuşak, kısık ve düşük bir sesle söylendiğini belirtir. }\end{array}$ \\
\hline : & $\begin{array}{l}\text { Uzatma } \\
\quad \text { Sesin } 0.2 \text { saniye süresince uzatıldığını gösterir. Süre uzadıkça simge sayısı artırılabilir. }\end{array}$ \\
\hline$\uparrow \downarrow$ & $\begin{array}{l}\text { Düşen/yükselen tonlama } \\
\quad \text { Tonlama ya da sesin düşmesi ya da yükselmesini ifade eder. }\end{array}$ \\
\hline$><$ & $\begin{array}{l}\text { Hizlı konuşma } \\
\quad \text { İki simgenin arasında yer alan konuşmanın diğer konuşmalardan daha hızlı şekilde } \\
\text { gerçekleştirildiğini gösterir. }\end{array}$ \\
\hline.$h$ & $\begin{array}{l}\text { Nefes alma } \\
\quad \text { Duyulabilir oranda nefes alındığını gösterir. Süre uzadıkça simge sayısı artırılabilir. }\end{array}$ \\
\hline
\end{tabular}

Not. Jefferson (2004) ve Sert ve arkadaşlarından (2015a) yararlanılarak hazırlanmıştır.

Yirmi sekizinci satıra gelindiğinde ise terapist sorduğu iki soruyla ilgili yanıtlar 1ş1ğında bir çıkarım yapmaktadır. Bu çıkarımın terapistin danışanın yanıtlarını anladığını gösterme ve anlaşılabilirliği artırma amacı taşıyor olduğu görülmektedir. Terapistin bu 
satırdaki cümleyi “olduğu” vurgusuyla tamamlanmamış olarak bıraktığg ve kısa bir sessizlikten sonra danışanın iki onay ifadesiyle yanıt verdiği görülmektedir. Hem eksik tasarlanmış sözceyle, hem de kısa bir sessizlikle terapist konuşma içinde danışanın söz sırası alabileceği, geçişe uygun bir nokta (Sert ve ark., 2015a) oluşturmaktadır. Eksik tasarlanmış sözcelerin bir sonraki konuşmacının katılımına zemin oluşturması eğitimsel etkileşimlere dayalı Türkçe araştırmalarda da karşımıza çıkmaktadır (Kardaş İşler, Şahin ve Balaman, 2019; Sert, 2016). Schegloff (2007) bu tür stratejileri "konumlandırma" olarak tanımlamış ve yeğleme düzenini şekillendirmek için bazı geçişe uygun noktalar kullanılabileceğini belirtmiştir (s. 67). Ona göre konuşmacılar konumlandırma yoluyla diğer konuşmacının yanıtı hakkında bir fikir sahibi olmaya çalışmaktadır. Örneğin, diğer konuşmacı yeğlenmeyen bir yanıta yönelik bir ipucu verirse, işbirliği şansını artırmak için bitmemiş söz sırası yeniden düzenlenebilir. Bu durumda, danışanın "evet" ve "aynen" şeklinde onaylamalarıyla terapist 31. satırda danışanın konuşmasıyla örtüşür şekilde cümlesini bitirmekte ve amaçlanan sosyal eylemin tamamlandığı görülmektedir. Ten Have (2007) bu tür örtüşmelerin yeğlenen tepkilerle karakterize etkileşimlerde sıklıkla gözlemlendiğini, bu etkileşimlerde çoğunlukla ön-genişletme gibi araçların kullanılmadığı ve gecikmeksizin hızlı yanıtlar verildiğini iletmektedir.

Kurumsal etkileşim açısından yukarıdaki çözümlemeler terapistin dizi düzenini başlatan, danışanı bir sonraki konuşmacı olarak seçen, soru soran, çıkarım yapan bir rol üstlendiğini göstermektedir. Terapist bunu yaparken özellikle danışanın katkılarını genişleten ve çeşitli kaynaklarla (örn., art-genişletme, eksik tasarlanmış sözce) yeni katk1lara zemin hazırlayan, firsat sağlayan ve bu katkıları cesaretlendiren bir etkileşim tasarlamaktadır. Danışanın ise bu bağlam içinde söz sırası verilen ve soruları yanıtlayan taraf olduğu söylenebilir. Bu yanıtların hızlı ve yeğlenen cevaplardan oluşması danışanın da bu rolü ortaya koyarken terapistle ortak bir etkileşimsel amaç taşıdığını düşündürtmektedir. Görüldüğü üzere, bu örnekte bu anlamdaki çıkarımlar kelime seçiminden ziyade dizi düzeninin mikro dinamiklerinden yola çıkılarak gerçekleştirilebilmiştir.

\section{Psikoterapinin Etkileri Üzerine Çalışmalar}

Psikoterapinin etkileri üzerine $\mathrm{KÇ}$ çalışmaları psikoterapi araştırmalarının tarihçesi kapsamında değinilen süreç ve süreç-sonuç araştırmalarının bir parçası olarak psikoterapinin etkili olup olmadığını ve etkili olmasında nasıl bir sürecin rol oynadığını anlamayı hedeflemekte ve KÇ alan yazınında özellikle son yıllarda önemli bir yer tutmaktadır. Perakyla ve arkadaşları (2008) yaklaşık 10 yıl önce doğrudan bu soruyu 
yanıtlamayı amaçlayan KÇ çalışmalarının eksikliğinden söz etmekle beraber her bir dizi düzeninde gerçekleşen terapötik eylemlerin incelenmesi ile gözlemlenen seans-içi değişimlerin, psikoterapinin mikro düzeydeki etkilerine dair bilgiler verdiğini öne sürmüşlerdir. Buradan hareketle KÇ’nin süreç-sonuç ve sonuç araştırmaları için önemli bir potansiyel taşıdığını söylemiş ve bu alandaki çalışmalara yönelik ihtiyacın altını çizmişlerdir. Takip eden süreçte ise gerçekleştirilen çalışmaların gerek problem alanları, gerekse psikoterapi yaklaşımları ve belirli yaklaşımlara özgü değişim mekanizmaları gibi oldukça geniş bir yelpazede yer alan konuları incelediği ve psikoterapi pratiğine dair yol gösterici sonuçlar ortaya koyduğu görülmektedir.

Danışan özelliklerine göre psikoterapi sürecinin ve süreçte değişen etkileşimin incelenmesi psikoterapinin etkileriyle ilgili araştırma alanlarından biri olagelmiştir. Yapılan çalışmalar psikoterapi etkileşiminin belirli problem alanları ya da danışan özelliklerine göre kendine özgü nitelikler taşıdığını göstermektedir. Dikkat Eksikliği ve Hiperaktivite Bozukluğu (McHoul ve Rapley, 2005), bağımlılık (Arminen, 2004), psikoz (Wise ve Rapley, 2009), psikosomatik yakınmalar (Burbaum ve ark., 2010) gibi problem alanlar1na özgü etkileşimleri inceleyen çalışmaların yanı sıra psikoterapide kendine özgü ihtiyaçları olduğu düşünülen HIV/AIDS hastaları (Kinnell ve Maynard, 1996), çocuklar (O’Reilly ve Parker, 2013), intihar girişiminde bulunmuş ergenler (Barriga ve Villalta, 2019), ileri düzey kanser hastaları (Shaw ve ark., 2017) gibi danışanlarla yürütülen süreçlerde ön plana çıkan etkileşimsel özellikler de araştırma konularını oluşturmuştur. Örneğin, Arminen (2004) Adsız Alkolikler gruplarında ikinci ağızdan anlatılan hikayelerin daha az dirençle karşılandığını tespit etmiştir. Shaw ve arkadaşları (2017) ise yaşamlarının son evrelerinde olan kanser hastalarıyla yapılan psikoterapilerde terapistlerin sorularında danışanların deneyimlerinin anlamlarına yöneldiğini, etkileşimin büyük kısmında doğrulama ve onaylama işlevi taşıyan etkileşimsel araçları tercih ettiklerini göstermişlerdir.

Çeşitli psikoterapi yönelimleri çerçevesinde gerçekleştirilen uygulamaların etkileri de psikoterapi sürecinin değerlendirilmesi için KÇ’den yararlanılan alanlardan biridir. Psikoterapide değişimin nasıl ve hangi etkileşimsel araçlar yoluyla gerçekleşebildiği bu çalışmaların temel sorularının başında gelmektedir. Örneğin, Keselman, Osvaldsson Cromdal, Kullgard ve Holmqvist (2018) yaptıkları çalışmada, kısa süreli ilişkisel bir terapide danışanların zihinselleştirme (mentalization) amaçlı müdahalelere yönelik direnç gösterdiği dizi düzenlerini incelemiş ve süreç içinde danışanların dirençlerini ortaya 
koyma biçimlerinde bir değişim gözlemlemişlerdir. Bu değişimin, psikoterapi çalışmasının bir etkisi olarak gelişmekte olan zihinselleştirme kapasitesini yansıttığını düşünmüşlerdir. Farklı yaklaşımların karşılaştırılması yoluyla da psikoterapinin etkileri çözümlenebilmektedir. Kondratyuk ve Perakyla (2011) varoluş̧̧u ve bilişsel yaklaşımla gerçekleştirilen psikoterapi seanslarının video kayıtlarını incelemiş; şimdi ve burada olma deneyimleri açısından varoluşçu terapinin bilişsel terapiden belli açılardan farkl1laştığını bulmuşlardır. Örneğin, her iki yaklaşımın da terapide ortaya çıkan anlık durumları ele aldığı, ancak varoluşçu terapistlerin farklı olarak danışanları özellikle şimdi ve burada olmaya davet ettikleri görülmüştür.

Perakyla (2019) alan yazındaki bulguları derlediği çalışmasında farklı yaklaşımlarla yürütülen psikoterapilerde çeşitli deneyimlerin değişiminde ortak olan bir eylem düzeni belirlemiştir. Ona göre terapistler hangi müdahaleyi gerçekleştiriyor ya da ilişkisel örüntüyü hayata geçiriyor olursa olsun tipik olarak önce bir ön eylem (örn., soru) gerçekleştirmekte ve bunu bir hedef eylem (örn., kavramsallaştırma) ile devam ettirmektedir; ardından danışandan bir karşılık (örn., red) gelmektedir. Son olarak, terapistler Perakyla'nın (2019) üçüncü konum (third position) olarak adlandırdığı eylemleri (örn., yeniden kavramsallaştırma) gerçekleştirmektedir. Özellikle üçüncü konum eylemleri yoluyla değişimin sağlanabildiğini ileri süren Perakyla (2019) bu düzen içinde seanslar boyunca görülen değişiklikleri incelemenin süreç içinde nasıl bir terapötik değişimi de beraberinde getirdiğini anlamayı kolaylaştıracağı sonucuna varmıştır.

KÇ çalışmaları uzun yıllar yalnızca psikoterapi süreci ile ilgili bilgi vermiş olsa da son yıllarda sonuç araştırmalarının da ilk örnekleriyle karşılaşılmaktadır. Gelecek birkaç yılda daha da artması öngörülen (Elliott, 2010; Perakyla, 2019; Perakyla ve ark., 2008) bu çalışmalarda psikoterapide niteliksel olarak neyin değiştiği sorusunun cevab1 aranmaktadır. Örneğin, Voutilainen, Perakyla ve Ruusuvuori (2011) inceledikleri psikoterapi etkileşiminde danışana ait hayal kırıklığı ve öfke duygularının kendini suçlamaya dönüştüğ̈̈ örüntülerde bir değiş̧im olduğunu bulmuşlardır.

Süreç ve sonuç araştırmalarının bir kısmında KÇ nicel bulguları desteklemek, doğrulamak ya da daha derinlemesine anlamayı sağlamak amacıyla yine nicel yöntemlerle birlikte de kullanılmaktadır. Lepper ve Mergenthaler (2008) seanslar boyunca ortaya çıkan klinik olarak anlamlı olayları önce nicel bir yöntem olan terapötik döngü modeli (Therapeutic Cycles Model) ile belirlemiş, ardından bu anlarda tam olarak nasıl bir etki- 
leşim gerçekleştiğini KÇ ile derinlemesine incelemiştir. Böylece hem daha geniş hem de küçük ölçekte psikoterapinin sonuçları değerlendirilebilmiştir. Benzer şekilde, Friedlander ve arkadaşları (2012) psikoterapideki onarıcı deneyimleri araştırdıkları çalışmada başarıyla sonuçlanmış kısa süreli psikodinamik terapide hem öz-bildirim araçları olarak anketler kullanmış, hem de anket sonuçlarını destekler şekilde terapist-danışan konuşmaları içinden onarıcı deneyimlere dair örnekler sunmuştur. Son olarak, Kontunen, Weiste, Liukkonen, Timonen ve Aaltonen (2019) kişilerarası danışmanlık almış olan depresif vakalarda nicel olarak ölçülen değişim oranlarını dikkate alarak başarılı olduğu ya da olmadığını belirledikleri süreçleri içerik analizi ve KÇ ile karşılaştırmışlardır. Başarısız vakalarda kavramsallaştırmaların tek yönlü olduğunu, ayrıca bu vakalarda çözülemeyen sorun alanlarının komplike yas ya da yalnızlık gibi konularla ilişkili olduğunu belirlemişlerdir.

\section{TARTIŞMA}

Psikoterapi araştırmaları ilk psikoterapi uygulamalarıyla birlikte gelişmeye başlamış ve epistemolojik olarak pek çok farklı bakış açısı ve yöntemsel olasılığı beraberinde getirmiştir. KÇ bu olasılıklar içinde anlam temelli paradigma kapsamında değerlendirilmektedir (Kuş, 2007; Rapley, 2012). Yukarıda belirtildiği gibi doğal konuşmalar içinde gerçekleşen sosyal eylemleri inceleme amacı taşıyan KÇ, psikoterapide de gerçekleşen etkileşimlerin mikro özelliklerini ve psikoterapi süreci ve sonuçlarıyla ilgili anlamlarını ele almaktadır (Perakyla ve ark., 2008).

KÇ’nin yöntemsel olarak kendine özgü özellikleri pek çok açıdan psikoterapi alanına katkıda bulunmakta ve araştırmalarda karşılaşılan kimi sorunlara çözüm getirme potansiyeli taşımaktadır (Madill ve ark., 2001). Öncelikle, psikoterapi araştırmalarının tarihselliği içinde değerlendirildiğinde KÇ özellikle pozitivist paradigmaya getirilen en temel eleştirilerden biri olan araştırmaların terapi odalarının öznelerarası doğasından uzaklaşması sorununu tamamen ortadan kaldırmaktadır. Braakmann (2015) bireysel vaka çalışmaları ile başlayan araştırmaların pozitivist yöntemlerle nesnel bir nitelik kazandığı, ancak nitel yöntemlerin gelişmesiyle birlikte bir noktada nesnellikten anlama ve öznelliğe geri dönüşün gerçekleştiğini vurgulamaktadır. Bu noktada KÇ ilk vaka çalışmalarında olduğu gibi öznel anlamları ön plana çıkarmakla kalmayıp, vaka çalışmalarının kısıtlılıklarının üstesinden gelmeye yardımcı olmaktadır. Şöyle ki, KÇ raporlarında çeviriyazı sembolleriyle yazıya dökülen alıntılar sunulmakta ve yapılan çözümleme bu 
alıntılara atıfta bulunarak açıklanmaktadır. Böylece araştırmacılar vardıkları sonuçları ve yaptıkları yorumları konuşmanın hangi özelliklerine dayandırdıklarını açıkça gösterebilmektedir. Bu durum veriyi yalnızca araştırmacının yakından incelemesini değil, okuyucuların da psikoterapideki konuşmalara birinci elden ulaşmasını ve hatta kendi çözümlemelerini gerçekleştirebilmelerini sağlamaktadır denilebilir. Sert ve arkadaşları (2015a) bu açıdan bakıldığında KÇ’nin geçerlilik ve güvenilirliği yüksek, belli ölçüde nesnel bir yöntem olarak değerlendirilebileceğini ileri sürmektedirler. Ancak bu noktada nesnellikten kastedilen, pozitivist yönteme dayalı araştırmalarda olduğundan farklı şekilde, öznelerarası ve öznel etkileşimlerin içeriden bakış açısını yansııtır şekilde konuşma organizasyonunda yer alan dile dair öğelerden kanttlar getirilerek çözümlenmesidir. Kısacası, etkileşim öznelerarası ve öznel bir süreç olarak ele alınmakta, bu öznellik araştırmacının yöntemsel ve bireysel ön kabulleri dışarıda tutularak anlaşılmaya çalış1maktadır.

KÇ’nin psikoterapideki etkileşimi öznelerarası bağlamda ele alıyor oluşu psikoterapi alan yazınında danışan-psikoterapist ilişkisi üzerine yürütülen tartışmalar için de bir takım anlamlar taşımaktadır. Psikoterapi alanında özellikle yeni nesil aktarım-karşı aktarım alan yazını ve bazı psikoterapi okulları (örn., ilişkisel psikanaliz) klasik psikoterapi yaklaşımlarını eleştirerek, psikoterapi sürecinin yalnızca danışana içkin bir patolojinin terapistin ya da araştırmacının dışarıdan bakış açısından değerlendirilmesinin ve kültürel bağlamın psikoterapi odasının tamamen dışında tutulabileceği inancının sorunlu yönlerine işaret etmiştir ${ }^{4}$. Georgaca ve Avdi (2009) bu bakış açısıyla paralel şekilde KÇ’nin psikoterapi sürecinin ortaklaşa şekilde inşa edilen, kurumsal ve kültürel özelliklere duyarlı şekilde anlaşılmasını sağlayan bir yöntem oluşuna işaret etmektedir. Psikoterapide henüz ilk KÇ çalışması olan Davis'in (1986) araştırmasında kavramsallaştırmalarda "tam zamanlı bir ev kadını" ve "anne" olma konularının nasıl ele alındığının incelenmesi feminist kuram çerçevesinde tartışılmıştır. Günümüzde de benzer çalışmalar ile araştırmacılar KÇ'yi kullanarak psikoterapide güç ilişkileri gibi konulara eğilebilmektedir (örn., Weiste ve ark., 2016). Ancak bu noktada yazının önceki bölümlerinde belirtildiği gibi KÇ'nin bunu söylem analizinde olduğu gibi sosyal konum alış vb. kavramlarla değil, budunyöntembilimsel kayıtsızlığa dayalı olarak gerçekleştirdiğini hatırlamakta fayda vardır.

4 Konuyla ilgili temel bir metin olarak bkz. Mitchell, 1988. 
KÇ ile yürütülen psikoterapi çalışmalarının tarihsel seyrine baktığımızda dilbilim ve sosyoloji alanlarının öncülüğünde başlayan araştırmaların kavramsallaştırmalar başta olmak üzere psikoterapideki belirli müdahaleleri yakından inceleyerek devam ettiği, bugün ise terapötik ilişki ya da sonuç araştırmaları gibi konuların ön plana çıktığı görülmektedir. Perakyla (2019) da KÇ çalışmalarının psikoterapi pratiğine dair meseleleri anlama noktasında gittikçe güçlendiğini dile getirmektedir. KÇ araştırmaları uzun süre psikoterapinin bir parçası olan belirli etkileşimleri derinlemesine anlamaya çalışmıştır. Bunda KÇ’nin yöntemsel olarak sıra-sıra ve konuşmanın en küçük detaylarına odaklı bir analiz oluşunun önemli bir etkisi vardır. Ayrıca KÇ çalışmalarında psikoterapi uygulamalarına dair resmin tamamını açığa çıkarmak terapistlerin ve psikoterapinin uygulamaya yönelik ihtiyaçlarının daha da uygun şekilde karşılanmasına yardımcı olacaktır. Halihazırda bir psikoterapi sürecini bütünüyle baştan sona inceleyen (örn., Voutilainen ve ark., 2011), vakaları (örn., Dilekler, 2018) ya da yaklaşımları (örn., Kondratyuk ve Perakyla, 2011) karşılaştıran çalışmalardan yola çıkarak gelecek çalışmalarda da bu yönde bir eğilim olacağı tahmin edilebilir. Ek olarak, Buchholz ve Kachele (2017) KÇ'nin klinik ihtiyaçları daha etkin şekilde karşılayabilmesi için yöntem olarak da kimi açılardan geliştirilebileceğini düşünmüş ve sıra-sıra çözümlemeler yerine konuşmanın daha büyük parçalar halinde nasıl çözümlenebileceği ile ilgili önerilerde bulunmuştur.

Biggerstaff (2012) psikolojide kullanılan nitel yöntemleri gözden geçirmiş ve günümüzde gelinen noktada nitel ve nicel, diğer bir deyişle pozitivist ve yorumsamacı yöntemlerin bir yelpaze dahilinde birlikte düşünülebileceğini dile getirmiştir. Bu durum KÇ için de geçerlidir. Her ne kadar ilgilendiği konular ve analiz yöntemi günden güne psikoterapinin ihtiyaçlarına daha uygun hale gelse de KÇ’nin tek başına her türlü psikoterapi sorusuna cevap verebilir olduğunu düşünmek gerçekçi olmayacaktır. Bu noktada KÇ araştırmalarının yakın geleceği için gerek diğer nitel yöntemler gerekse nicel veriler ile birlikte kullanıldı̆̆ı karma yöntemli çalışmalar umut verici görülmektedir (örn., Kontunen ve ark., 2019).

Psikoterapide KÇ ile yürütülen araştırmaların süreçte ve psikoterapinin sonunda elde edilen değişimin nasıl gerçekleştiğine dair ortaya koyduğu bilgiler psikoterapistler için kendi etkileşimlerini şekillendirmelerinde yol gösterici olacaktır. O’Reilly ve Lester (2019) günümüz psikoterapi araştırmalarında kanıta dayalı yaklaşıma dikkat çekmekte, terapistin klinik uzmanlığı kadar danışanın koşullarına duyarlı olmasının en iyi pratik olarak görüldüğünü hatırlatmaktadır. Yazarlara göre, KÇ bağlama ve kişiye özgü nite- 
likleri anlamaya yardımcı olmakla hem psikoterapi uygulamalarına devam eden hem de psikoterapi eğitimindeki klinisyenlere bu anlamda yeni bakış açıları kazandıracaktır. Uygulamacılar KÇ araştırmalarına aşina oldukça kendilerinin de psikoterapide dili nasıl kullandıkları ve etkileşimin hangi noktada nasıl nitelikler kazandığ gibi etkileşimsel detaylarla ilgili farkındalıklarını artırabileceklerdir. Perakyla (2011) bir psikanalist adayı olarak yazdığı yazısında aynı zamanda bir araştırmacı olarak KÇ yapmanın psikoterapi pratiğine oldukça önemli katkıları olduğunu dile getirmiş ve deneyimini paylaşmıştır. Hem seans sırasında etkileşimin en küçük detaylarına dair ipuçlarını daha kolay fark ederek hem de seanslarını KÇ bulguları ışığında tekrar gözden geçirerek terapistlik becerilerini geliştirdiğini anlatmıştır. Bu noktada KÇ’nin gerek ses kayıtlarının çeviriyazı simgeleriyle yazıya dökülmesi yoluyla veri kaybını en aza indirmesi, gerekse çokkiplilik ekseninde ilerlemesi sonucunda video görüntülerini de analiz etmeye uygun oluşu ile bu yöntem psikoterapi alanındaki tüm çalışmaları yöntemsel olarak güçlendirmekle kalmayıp psikoterapist adaylarının mesleki eğitimlerine de çok daha zengin katkılarda bulunmaktadır. Bu durum ayrıca başka kimi nitel araştırma yöntemleriyle analiz edilemeyecek kadar mikro düzeydeki görsel ve sözel olmayan veriyi de çözümlemeye dahil etmesi açısından KÇ’nin psikoterapi araştırmalarına ek bir katkısı olarak değerlendirilebilir.

Özetle KÇ, psikoterapi araştırmaları içinde son yıllarda önemli gelişme gösteren, psikoterapiyi bir sosyal etkileşim olarak gören ve bulgularıyla pratiğe yönelik dikkate değer katkılarda bulunan bir yöntem olmuştur. Uluslararası alan yazında daha geniş bir çalışma alanı bulmuş olmasına rağmen Türkiye'de gerçekleştirilen çalışmaların henüz başlangıç aşamasında olduğu söylenebilir. Bu durum ülkemizdeki kimi psikoterapi çalışmalarında yer yer ortaya çıkan, KÇ’nin uygulanmasında birtakım yöntemsel eksiklerin de oluşmasıyla sonuçlanıyor gibi görünmektedir. Örneğin Bulut’un (2019) sessizliğin psikoterapideki işlevlerini anlamayı amaçlayan çalışması psikanalitik yönelimli psikoterapi pratiği açısından oldukça önemli bir araştırma sorusunu ele almakla birlikte, bunu yaparken KÇ'nin gerekliliklerinin bir kısmını yansıtamadığı görülmektedir. Araştırmacı bu çalışmada Sert ve arkadaşlarının (2015a) altını çizdiği gibi yorumlamalarını tam olarak konuşmacıların içeriden bakış açısına dayandıracak şekilde söz sırası alma, onarım, yeğleme ve dizi düzeni gibi etkileşimsel kaynaklar aracılığıyla sunmamaktadır. Hem araştırmaların sayıca az oluşu, hem de tam da bu çalışmada olduğu gibi yöntemsel sorunların varlığı ülkemizde kurumsal etkileşimlerin genelinde ve psikoterapi özelinde 
KÇ alan yazınının yeni bilgi ve deneyimlere ihtiyaç duyduğunun göstergesidir. Ayrıca Türkiye'deki çalışmaların gelişmesi ile uluslararası psikoterapi alan yazınına yönelik katkıları artırmak, ülkemizdeki psikoterapi uygulamalarına dair bilgileri genişletmek, kültüre özgü konuların psikoterapideki yansımalarına dair daha detaylı bir izlenim kazanmak mümkün olacaktır.

\footnotetext{
Hakem Değerlendirmesi: Dış bağımsız.

Çıkar Çatışması: Yazar çıkar çatışması bildirmemiştir.

Finansal Destek: Yazar bu çalışma için finansal destek almadığını beyan etmiştir.
}

Peer-review: Externally peer-reviewed.

Conflict of Interest: The author has no conflict of interest to declare.

Grant Support: The author declared that this study has received no financial support.

\section{Kaynakça/References}

Ablon, J. S., Levy, R. A. ve Smith-Hansen, L. (2011). The contributions of the psychotherapy process Q-set to psychotherapy research. Research in Psychotherapy: Psychopathology, Process and Outcome, 14(1), 14-48. https://doi.org/10.4081/ripppo.2011.46

Antaki, C. (2008). Formulations in psychotherapy. A. Perakyla, C. Antaki, S. Vehvilainen, ve I. Leudars (Ed.), Conversation analysis and psychotherapy içinde (s. 26-42). Cambridge University Press.

Antaki, C., Barnes, R. ve Leudar, I. (2005). Diagnostic formulations in psychotherapy. Discourse Studies, 7(6), 627-647. https://doi.org/10.1177\%2F1461445605055420

Arkonaç, S. A. (2014). Psikolojide söz ve anlam analizi: Niteliksel duruş. Ayrıntı Yayınları.

Arminen, I. (2004). Second stories: The salience of interpersonal communication for mutual help in Alcoholics Anonymous. Journal of Pragmatics, 36, 319-347. https://doi.org/10.1016/j.pragma. 2003.07.001

Atkinson, J. M. ve Heritage, J. (1999). Transcript notation - structures of social action: Studies in conversation analysis. Aphasiology, 13(4-5), 243-249. https://doi.org/10.1080/026870399402073

Avdi, E. ve Georgaca, E. (2007). Discourse analysis and psychotherapy: A critical review. European Journal of Psychotherapy and Counselling, 9(2), 157-176. https://doi. org/10.1080/13642530701363445

Baltacı, S. ve Gençöz, F. (2019). Psikolojide Lacanyen söylem analizi yaklaşımı: Madde bağımlılığı ve yasa ilişkisinin terapi sürecinde incelenmesi örneği. AYNA Klinik Psikoloji Dergisi, 6(1), 38-62. https://doi.org/10.31682/ayna.482168

Barriga, L. ve Villalta, M. (2019). Analysis of the conversation: Psychotherapy of depressed adolescents with attempted suicide in a hospital context. Terapia Psicologica, 37(1), 39-51. http://teps.cl/index. $\mathrm{php} /$ teps/article/view/246

Bartesaghi, M. (2009). Conversation and psychotherapy: How questioning reveals institutional answers. Discourse Studies, 11(2), 153-177. https://doi.org/10.1177\%2F1461445608100942

Bercelli, F., Rossano, F. ve Viaro, M. (2008). Clients' responses to therapists' reinterpretations. A. Perakyla, C. Antaki, S. Vehvilainen ve I. Leudars (Ed.), Conversation analysis and psychotherapy içinde (s. 43-61). Cambridge University Press. 
Biggerstaff, D. (2012). Qualitative research methods in psychology. G. Rossi (Ed.), Psychology: Selected papers içinde (s. 175-206). InTech.

Bordin, E. S. (1979). The generalizability of the psychoanalytic concept of the working alliance. Psychotherapy: Theory, Research \& Practice, 16(3), 252-260. https://doi.org/10.1037/h0085885

Braakmann, D. (2015). Historical paths in psychotherapy research. O. Gelo, A. Pritz ve B. Rieken (Ed.), Psychotherapy research içinde (s. 39-65). Springer.

Breuer, J. ve Freud, S. (1957). Studies on hysteria. Basic Books.

Buchholz, M. B. ve Kachele, H. (2017). From turn-by-turn to larger chunks of talk: An exploratory study in psychotherapeutic micro-processes using conversation analysis. Research in Psychotherapy: Psychopathology, Process and Outcome, 20, 161-178. https://doi.org/10.4081/ripppo.2017.257

Buchholtz, M. B., Spiekermann, J. ve Kachele, H. (2015). Rhythm and blues- Amalie's 152nd session: From psychoanalysis to conversation and metaphor analysis-and back again. The International Journal of Psychoanalysis, 96(3), 877-910. http://doi.org/10.1111/1745-8315.12329

Bulut, B. P. (2019). Psikanalitik yönelimli psikoterapi seanslarındaki sessizliğin konuşma analizi ile incelenmesi. AYNA Klinik Psikoloji Dergisi, 6(1). 63-84. https://doi.org/10.31682/ayna.503291

Burbaum, C., Stresing, A. M., Fritzsche, K., Auer, P., Wirsching, M. ve Lucius-Hoene, G. (2010). Medically unexplained symptoms as a threat to patients' identity?: A conversation analysis of patients' reactions to psychosomatic attributions. Patient Education and Counseling, 79(2), 207217. https://doi.org/10.1016/j.pec.2009.09.043

Büyükgüzel, S. ve Gül, S. (2015). Tartışmada örtüşme ve örtüşmelerin çözümü. Mersin University Journal of Linguistics \& Literature/Mersin Üniversitesi Dil ve Edebiyat Dergisi, 12(2), 95-113. http://ded.mersindilbilim.info/tr/pub/issue/19515/207876

Cardoso, C., Pinto, D. ve Ribeiro, E. (2019). Therapist's actions after therapeutic collaboration breaks: A single case study. Psychotherapy Research, Advance online publication. https://www.tandfonline. com/doi/full/10.1080/10503307.2019.1633483

Clarke, V. ve Braun, V. (2018). Using thematic analysis in counselling and psychotherapy research: A critical reflection. Counselling and Psychotherapy Research, 18(2), 107-110. https://doi. org/10.1002/capr.12165

Creswell, J. W. (2013). Nitel araştırma yöntemleri: Beş yaklaşıma göre nitel araştırma ve araştırma deseni (3. Baskıdan çeviri) (M. Bütün, S. B. Demir, Çev. ed.). Siyasal Kitabevi.

Davis, K. (1986). The process of problem (re)formulation in psychotherapy. Sociology of Health and Illness, 8(1), 44-74. https://doi.org/10.1111/1467-9566.ep11346469

Dilekler, İ. (2018). Intersubjectivity in psychotherapy: Perspectives of sadomasochism and conversation analysis (Yayınlanmamış Doktora Tezi). Middle East Technical University, Ankara.

Elliott, R. (2010). Psychotherapy change process research: Realizing the promise. Psychotherapy Research, 20(2), 123-135. https://doi.org/10.1080/10503300903470743

Elliott, R. ve Farber, B. A. (2010). Carl Rogers: Idealistic pragmatist and psychotherapy research pioneer. L. G. Castonguay, J. C. Muran, L. Angus, J. A. Hayes, N. Ladany ve T. Anderson (Ed.), Bringing psychotherapy research to life: Understanding change through the work of leading clinical researchers içinde (s. 17-27). American Psychological Association.

Emanuela, C. ve Carmela, M. (2013). Clinical psychology and research: Epistemological notes, Mediterranean Journal of Clinical Psychology, 1(1), 1-9. https://doi.org/10.6092/2282-1619/2013. 1.900

Emil Ögünç, N. ve Eren, N. (2012). Borderline kişilik bozukluğu gösteren hastalarda psikodinamik grup psikoterapi sürecinin nesne ilişkileri üzerine etkileri. Psikiyatri Hemşireliği Dergisi, 3(1), 3037. $10.5505 /$ phd.2012.20591 
Eysenck, H. J. (1952). The effects of psychotherapy: An evaluation. Journal of Consulting Psychology, 16(5), 319-324. https://psycnet.apa.org/doi/10.1037/h0063633

Fitzgerald, P. (2013). Therapy talk: Conversation analysis in practice. Palgrave Macmillan.

Fox, D., Prilleltensky, I. ve Austin, S. (2009). Eleştirel psikoloji (G. Kayacı Sevinç, İ. Demirok, B. Gürsel, Çev.). İstanbul: Ayrıntı Yayınları.

Friedlander, M. L., Sutherland, O., Sandler, S., Kortz, L., Bernardi, S., Lee, H. H. V. ve Drozd, A. (2012). Exploring corrective experiences in a successful case of short-term dynamic psychotherapy. Psychotherapy, 49(3), 349-363. https://doi.org/10.1037/a0023447

Garfinkel, H. (1967). Studies in ethnomethodology. Prentice-Hall.

Gelso, C. J. ve Hayes, J. A. (2007). Countertransference and the inner world of the psychotherapist: Perils and possibilities. Mahwah, New Jersey: Erlbaum.

Georgaca, E. ve Avdi, E. (2009). Evaluating the talking cure: The contribution of narrative, discourse, and conversation analysis to psychotherapy assessment. Qualitative Research in Psychology, 6(3), 233-247. https://doi.org/10.1080/14780880802146

Gonçalves, M. M. ve Angus, L. (2017). Narrative measures in psychotherapy research: Introducing the special section. Psychotherapy Research, 27(3), 251-252. https://psycnet.apa.org/doi/10.1080/105 03307.2016.1265687

Grzanka, P. R. ve Miles, J. R. (2016). The problem with the phrase "intersecting identities": LGBT affirmative therapy, intersectionality, and neoliberalism. Sexuality Research and Social Policy, 13(4), 371-389. 10.1007/s13178-016-0240-2

Gülüm, İ. V., Soygüt, G. ve Safran, J. D. (2018). A comparison of pre-dropout and temporary rupture sessions in psychotherapy. Psychotherapy Research, 28(5), 685-707. https://doi.org/10.1080/1050 3307.2016 .1246765

Haakana, M. (2010). Laughter and smiling: Notes on co-occurrences. Journal of Pragmatics, 42(6), 1499-1512. https://doi.org/10.1016/j.pragma.2010.01.010

Halonen, M. (2008). Person reference as a device for constructing experiences as typical in group therapy. A. Perakyla, C. Antaki, S. Vehvilainen ve I. Leudars (Ed.), Conversation analysis and psychotherapy içinde (s. 139-151). Cambridge University Press.

Harper, D. ve Thompson, (2012). Qualitative research methods in mental health and psychotherapy: A guide for students and practitioners. Wiley-Blackwell.

Heritage, J. (1998). Conversation analysis and institutional talk: Analyzing distinctive turn-taking systems. S. Cmejrkova, J. Hoffmannova, O. Müllerova ve J. Svetla (Ed.). Proceedings of the 6th International Congress of IADA (International Association for Dialog Analysis) içinde (s. 3-17). Niemeyer.

Heritage, J. ve Watson, D. R. (1979). Formulations as conversational objects. G. Psathas (Ed), Everyday language: Studies in ethnomethodology içinde (s. 123-162).Irvington.

Hunsley, J. ve Lee, C. M. (2010). Introduction to clinical psychology: An evidence-based approach. Hoboken: Wiley Global Education.

Hutchby, I. (2005). "Active listening": Formulations and the elicitation of feelings-talk in child counselling. Research on Language and Social Interaction, 38(3), 303-329. https://doi.org/10.1207/ s15327973rlsi3803_4

Hutchby, I. ve Wooffitt, R. (2008). Conversation analysis. Cornwall: Polity.

Jefferson, G. (2004). Glossary of transcript symbols with an introduction. G. H. Lerner (Ed.). Conversation analysis: Studies from the first generation içinde (s. 13-31). John Benjamins Publishing Company. 
Kardaş İşler, N., Şahin, A. E., ve Balaman, U. (2019). Öğrenci katılımına zemin hazırlayan etkileşimsel bir kaynak: Eksik tasarlanmış sözceler. Pamukkale Üniversitesi Eğitim Fakültesi Dergisi, 45(45), 376-396.

Keselman, H., Osvaldsson Cromdal, K., Kullgard, N. ve Holmqvist, R. (2018). Responding to mentalization invitations in psychotherapy sessions-A conversation analysis approach. Psychotherapy Research, 28(4), 654-666. https://doi.org/10.1080/10503307.2016.1219422

Kinnell, A. M. K. ve Maynard, D. W. (1996). The delivery and receipt of safer sex advice in pretest counseling sessions for HIV and AIDS. Journal of Contemporary Ethnography, 24(4), 405-437. https://doi.org/10.1177\%2F089124196024004002

Knox, S. ve Lutz, W. (2014). Quantitative and qualitative methods in psychotherapy research. Routledge.

Kondratyuk, N. ve Perakyla, A. (2011). Therapeutic work with the present moment: A comparative conversation analysis of existential and cognitive therapies. Psychotherapy Research 21(3), 316330. https://doi.org/10.1080/10503307.2011.570934

Kontunen, J., Weiste, E., Liukkonen, T., Timonen, M. V. ve Aaltonen, J. (2019). Predicting response to interpersonal counselling (IPC) from case formulation: A systematic comparison between recovered and unchanged depressive cases. Counselling Psychology Quarterly, Advance online publication. https://www.tandfonline.com/doi/full/10.1080/09515070.2019.1588101

Kuş, E. (2007). Sosyal bilim metodolojisinde paradigma dönüşümü ve psikolojide nitel araştırma. Türk Psikoloji Yazıları, 10(20), 19-41.

Larkin, M. ve Thompson, A. R. (2012). Interpretative phenomenological analysis in mental health and psychotherapy research. A. R. Thompson ve D. Harper (Ed), Qualitative research methods in mental health and psychotherapy: A guide for students and practitioners içinde (s. 99-116). WileyBlackwell.

Lemma, A. (2003). Introduction to the practice of psychoanalytic psychotherapy. Wiley.

Lepper, G. ve Mergenthaler, E. (2008). Observing therapeutic interaction in the "Lisa" case. Psychotherapy Research, 18(6), 634-644. https://psycnet.apa.org/doi/10.1080/10503300701442001

Levitt, H., Korman, Y. ve Angus, L. (2000). A metaphor analysis in treatments of depression: Metaphor as a marker of change. Counselling Psychology Quarterly, 13(1), 23-35. https://doi. org/10.1080/09515070050011042

MacMartin, C. (2008). Resisting optimistic questions in narrative and solution-focused therapies. A. Perakyla, C. Antaki, S. Vehvilainen ve I. Leudars (Ed.), Conversation analysis and psychotherapy içinde (s. 80-99). Cambridge University Press.

Madill, A., Widdicombe, S. ve Barkham, M. (2001). The potential of conversation analysis for psychotherapy research. The Counseling Psychologist, 29(3), 413-434. https://doi.org/10.1177/ 0011000001293006

McGee, D., Vento, A. D. ve Bavelas, J. B. (2005). An interactional model of questions as therapeutic interventions. Journal of Marital and Family Therapy, 31(4), 371-384. https://doi. org/10.1111/j.1752-0606.2005.tb01577.x

McHoul, A. ve Rapley, M. (2005). A case of attention-deficit/hyperactivity disorder diagnosis: Sir Karl and Francis B. slug it out on the consulting room floor. Discourse \& Society, 16(3), 419-449. https:// doi.org/10.1177\%2F0957926505051173

Mitchell, S. A. (1988). Relational concepts in psychoanalysis: An integration. Harward University Press. 
Mondada, L. (2019). Contemporary issues in conversation analysis: Embodiment and materiality, multimodality and multisensoriality in social interaction. Journal of Pragmatics, 145, 47-62. https://doi.org/10.1016/j.pragma.2019.01.016

Mörtl, K. ve Gelo, O. C. G. (2015). Qualitative methods in psychotherapy process research. O. C. G. Gelo, A. Pritz ve B. Rieken (Ed.). Psychotherapy research: Foundations, process, and outcome içinde (s. 381-428). Springer.

Muntigl, P. ve Horvath, A. O. (2014). "I can see some sadness in your eyes": When experiential therapists notice a client's affectual display. Research on Language and Social Interaction, 47(2), 89-108. https://doi.org/10.1080/08351813.2014.900212

Neustatter, W. L. (1935). The results of fifty cases treated by psychotherapy. The Lancet, 225(5823), 796-799. https://doi.org/10.1016/S0140-6736(00)56772-5

O'Reilly, M. ve Lester, J. (2019). Applied conversation analysis for counselling and psychotherapy researchers. Counselling and Psychotherapy Research, 19, 97-101. https://doi.org/10.1002/capr.12216

O'Reilly, M. ve Parker, N. (2013). 'You can take a horse to water but you can't make it drink': Exploring children's engagement and resistance in family therapy. Contemporary Family Therapy, 35(3), 491-507. https://doi.org/10.1007/s10591-012-9220-8

Perakyla, A. (2011). A psychoanalyst's reflection on conversation analysis's contribution to his own therapeutic talk. C. Antaki (Ed.). Applied conversation analysis: Intervention and change in institutional talk içinde (s. 222-242). Palgrave Macmillan.

Perakyla, A. (2013). Conversation analysis in psychotherapy. J. Sidnell ve T. Stivers (Ed.). The handbook of conversation analysis içinde (s. 551-574). Wiley-Blackwell.

Perakyla, A. (2019). Conversation analysis and psychotherapy: Identifying transformative sequences. Research on Language and Social Interaction, 52(3), 257-280. https://doi.org/10.1080/08351813. 2019.1631044

Perakyla, A., Antaki, C., Vehvilainen, S. ve Leudar, I. (2008). Analysing psychotherapy in practice. A. Perakyla, C. Antaki, S. Vehvilainen ve I. Leudars (Ed.), Conversation analysis and psychotherapy içinde (s. 5-25). Cambridge University Press.

Perakyla, A. ve Vehvilainen, S. (2003). Conversation analysis and the professional stocks of interactional knowledge. Discourse \& Society, 14(6), 727-750. https://doi.org/10.1177\%2F09579265030146003

Pittenger, R. E., Hockett, C. F. ve Danehy, J. J. (1960). The first five minutes: A sample of microscopic interview analysis. Paul Martineau.

Potter, J. ve Edwards, D. (2013). Conversation analysis and psychology. J. Sidnell ve T. Stivers (Ed.), The handbook of conversation analysis içinde (s. 701-725). Wiley-Blackwell.

Rapley, M. (2012). Ethnomethodology/Conversation analysis. D. Harper ve A. R. Thompson (Ed.). Qualitative research methods in mental health and psychotherapy: A guide for students and practitioners içinde (s. 177-192). Wiley-Blackwell.

Rieken, B. ve Gelo, O. C. G. (2015). The philosophy of psychotherapy science: Mainstream and alternative views. O. C. G. Gelo, A. Pritz ve B. Rieken (Ed.). Psychotherapy research: Foundations, process, and outcome içinde (s. 67-92). Springer.

Rozenzweig, S. (1936). Some implicit common factors in diverse methods of psychotherapy. American Journal of Orthopsychiatry, 6(3), 412-415. https://doi.org/10.1111/j.1939-0025.1936.tb05248.x

Sacks, H. (1992). Lectures on conversation (2 Cilt). Oxford: Basil Blackwell.

Sacks, H., Schegloff, E. ve Jefferson, G. (1974). A simplest systematics for the organization of turntaking for conversation. Language, 50(4), 696-735. https://doi.org/10.1016/B978-0-12-623550$0.50008-2$ 
Sarı, S. (2019). Terapi ilişkisinin terapist ve danışanın kaçınma örüntüleri açısından incelenmesi: Bir konuşma analizi çalışması. AYNA Klinik Psikoloji Dergisi, 6(2), 106-126. https://doi.org/10.31682/ ayna. 495378

Scheflen, A. E. (1973). Communicational structure: Analysis of a psychotherapy transaction. Indiana University Press.

Schegloff, E. A. (2007). Sequence organization in interaction: Volume 1: A primer. Cambridge University Press.

Sert, O. (2016). Sınıf içi etkileşim ve yabancı dil öğretmeni yetiştirme. Akcan, S. ve Bayyurt, Y. (Ed.). Türkiye'deki yabancı dil eğitimi üzerine görüş ve düşünceler içinde (s. 14-30). Boğaziçi Üniversitesi Yayınevi.

Sert, O., ve Balaman, U. (2015). Çevrimiçi görev-temelli etkileşimde ortaklaşa bilgi yapılandırmasının konuşma çözümlemesiyle incelenmesi. Mersin Üniversitesi Dil ve Edebiyat Dergisi, 12(2), 45 72.

Sert, O., Balaman, U., Daşkın, N. C., Büyükgüzel, S. ve Ergül, H. (2015a). Konuşma çözümlemesi yöntemi. Mersin Üniversitesi Dil ve Edebiyat Dergisi, 12(2), 1-43.

Sert, O., Bozbıyık, M., Elçin, M., ve Turan, S. (2015b). Standart hasta-tıp öğrencisi etkileşiminde ön bilgi iddiaları ve etkileşimsel sorunlar. Mersin Üniversitesi Dil ve Edebiyat Dergisi, 12(2), 4-25.

Shaw, C., Chrysikou, V., Davis, S., Gessler, S., Rodin, G. ve Lanceley, A. (2017). Inviting end-oflife talk in initial CALM therapy sessions: A conversation analytic study. Patient Education and Counseling, 100(2), 259-266. http://dx.doi.org/10.1016/j.pec.2016.08.024

Shean, G. D. (2013). Controversies in psychotherapy research: Epistemic differences in assumptions about human psychology. American Journal of Psychotherapy, 67(1), 73-87. https://doi.org/10.1176/ appi.psychotherapy.2013.67.1.73

Speer, S. (2010). Pursuing views and testing commitments: Hypothetical questions in the psychiatric assessment of transsexual patients. A. F. Freed ve S. Ehrlich (Ed.). Why do you ask: The function of questions in institutional discourse içinde (s. 133-158). Oxford University Press.

Stafford, V., Hutchby, I., Karim, K. ve O’Reilly, M. (2016). “Why are you here?" Seeking children's accounts of their presentation to Child and Adolescent Mental Health Service (CAMHS). Clinical Child Psychology and Psychiatry, 21(1), 3-18. https://doi.org/10.1177 \%2F1359104514543957

Sutherland, O. ve Strong, T. (2011). Therapeutic collaboration: A conversation analysis of constructionist therapy. Journal of Family Therapy, 33(3), 256-278. https://doi.org/10.1111/j.14676427.2010.00500.x

Ten Have, P. (2007). Doing conversation analysis: A practical guide (2. bask1). Sage

Thompson, A. R. ve Harper, D. (2012). Introduction. D. Harper ve A. R. Thompson (Ed.). Qualitative research methods in mental health and psychotherapy: A guide for students and practitioners içinde (s. 3-8). Wiley-Blackwell.

Vehvilainen, S. (2003). Preparing and delivering interpretations in psychoanalytic interaction. Text, 23(4), 573-606. https://doi.org/10.1515/text.2003.022

Vehvilainen, S. (2008). Identifying and managing resistance in psychoanalytic interaction. A. Perakyla, C. Antaki, S. Vehvilainen ve I. Leudars (Ed.), Conversation analysis and psychotherapy içinde s. 120-138). Cambridge University Press.

Voutilainen, L., Perakyla, A. ve Ruusuvuori, J. (2010). Recognition and interpretation: Responding to emotional experience in psychotherapy. Research on Language and Social Interaction, 43(1), 85107. https://doi.org/10.1080/08351810903474799 
Voutilainen, L., Perakyla, A. ve Ruusuvuori, J. (2011). Therapeutic change in interaction: Conversation analysis of a transforming sequence. Psychotherapy Research, 21(3), 348-365. https://doi.org/10.1 080/10503307.2011.573509

Wallerstein, R. S. (1989). The psychotherapy research project of the Menninger Foundation: An overview. Journal of Consulting and Clinical Psychology, 57(2), 195-205. https://psycnet.apa.org/ doi/10.1037/0022-006X.57.2.195

Weiste, E., Voutilainen, L. ve Perakyla, A. (2016). Epistemic asymmetries in psychotherapy interaction: Therapists' practices for displaying access to clients' inner experiences. Sociology of Health \& Illness, 38(4), 645-661. https://onlinelibrary.wiley.com/doi/full/10.1111/1467-9566.12384

Weiste, E. ve Perakyla, A. (2013). A comparative conversation analytic study of formulations in psychoanalysis and cognitive psychotherapy. Research on Language and Social Interaction, 46(4), 299-321. https://doi.org/10.1080/08351813.2013.839093

West, W. (2001). Beyond grounded theory: The use of a heuristic approach to qualitative research. Counselling and Psychotherapy Research, 1(2), 126-131. https://doi.org/10.1080/147331401123 31385168

Wise, M. J. ve Rapley, M. (2009). Cognitive behaviour therapy, psychosis and attributions of irrationality: Or, how to produce cognitions as 'faulty'. The Journal of Critical Psychology, Counselling and Psychotherapy, 9(4), 179-196.

Wynn, R. ve Wynn, M. (2006). Empathy as an interactionally achieved phenomenon in psychotherapy: Characteristics of some conversational resources. Journal of Pragmatics, 38(9), 1385-1397. https:// doi.org/10.1016/j.pragma.2005.09.008

Yao, X. L. ve Ma, W. (2017). Question resistance and its management in Chinese psychotherapy. Discourse Studies, 19(2), 216-233. https://doi.org/10.1177\%2F1461445617695700 